\title{
Federal and Local Jurisdiction in the District of Columbia
}

The 1982 trial of John Hinckley for the attempted assassination of President Ronald Reagan brought to the public's attention a unique feature of the criminal justice system in the District of Columbia. Although federal and state charges never are joined together for trial, federal and D.C. Gode charges may be joined in one indictment under section 11502(3) of the D.C. Code, ${ }^{1}$ and tried before the United States District Court for the District of Columbia. ${ }^{2}$

In the Hinckley case, the federal prosecutor used section 11-502(3) to join three federal and ten D.G. Code charges. This joinder required the district court to determine whether to use both federal and D.C. Code evidentiary standards during the trial, or only one standard. The court ruled that only federal standards would be used, ${ }^{3}$ and therefore placed the

1. Under D.C. CODE ANN. § 11-502(3) (1981), the United States District Court has jurisdiction over "[a]ny offense under any law applicable exclusively to the District of Columbia which offense is joined in the same information or indictment with any Federal offense." A similar but more limited jurisdictional statute is found at D.C. CODE ANN. § 23-311(b) (1981):

Two or more offenses may be charged in the same indictment or information as provided in subsection (a) [offenses charged are of similar character or based on same transaction] even though one or more is in violation of the laws of the United States and another is in violation of the laws applicable exclusively to the District of Columbia and may be prosecuted as provided in Section 11-502(3).

The requirements for the proper joinder of offenses under $\$ 23-311(\mathrm{a})$ are the same as those found in FED. R. CRIM. P. 8. See infra note 99. Despite the broad language of $\S 11-502(3)$, which on its face permits joinder of even unrelated federal and local offenses in one indictment, the D.C. Circuit has read the "proper joinder" requirements of rule 8 (also described in D.C. CODE ANN. § 23-311) into § 11-502(3). United States v. Kember, 648 F.2d 1354, 1359 (D.C. Cir. 1980); United States v. Jackson, 562 F.2d 789, 793 (D.C. Cir. 1977).

2. The federal courts in the District are the United States District Court for the District of Columbia, and the United States Court of Appeals for the District of Columbia Circuit. The local trial court is the Superior Court, and the local appellate court is the District of Columbia Court of Appeals.

3. The D.C. Circuit previously had ruled that the use of two evidentiary standards in the same trial is "patently nct feasible." United States v. Belt, 514 F.2d 837, 844 (D.C. Cir. 1975); see United States v. Hairston, 495 F.2d 1046, 1054 n.13 (D.C. Cir. 1974) (applying federal evidentiary standard for impeachment by prior conviction); United States v. Brown, 483 F.2d 1314, 1317-18 (D.C. Cir. 1973) (federal bail rules apply to defendant charged with D.C. Code offenses in federal court). But see United States v. Garnett, 653 F.2d 558, 560-61 (D.C. Cir. 1981) (refusing to decide whether federal or District probation provisions apply to D.C. Code violator in federal court); United States v. 
burden of disproving insanity upon the prosecution. In contrast, the D.C. Code places the burden of proof upon the defendant. ${ }^{4}$ This ruling may well have been the deciding factor in Hinckley's acquittal by reason of insanity.

This Note examines three alternative bases for the jurisdiction of the District's Article III courts ${ }^{5}$ over joined D.C. Code offenses. First, if the D.C. Code is defined as federal law, ${ }^{6}$ and D.C. Code offenses are considered "crimes against the United States," D.C. Code offenses fall within federal court "arising under" jurisdiction. ${ }^{8}$ Second, Article III jurisdiction

Greene, 489 F.2d 1145, 1153 (D.C. Cir. 1973) (D.C. Code insanity standard applicable to D.C. Code offenders in federal court), cert. denied, 419 U.S. 977 (1974); United States v. Brown, 483 F.2d 1314, 1320-23 (D.C. Cir. 1973) (MacKinnon, J., dissenting) (D.C. Code bail provisions should apply to D.C. Code violators in federal court).

4. D.C. CODE ANN. $\S 24-301$ (j) (1981); see Bethea v. United States, 365 A.2d 64, 93-95 (D.C. 1976) (upholding constitutionality of $\S 24-301(j)$ ), cert. denied, 433 U.S. 911 (1977).

5. The District's federal courts are established under Article III of the U.S. Constitution, D.C. CODE ANN. §11-101(1) (1981), and exercise the same judicial power of the United States as all other Article III courts, Palmore v. United States, 411 U.S. 389, 408-09 (1973); see also United States v. Jackson, 562 F.2d 789, 800 (D.C. Cir. 1977) ("A central purpose and policy of D.C. court reorganization was to assure that the prompt and effective discharge of [federal] responsibilities would not be impeded by the necessity of trying local criminal offenses, for which a forum was provided in an enlarged and strengthened local court system."); Andrade v. Jackson, 401 A.2d 990, 992 (D.C. 1979) (District's federal courts divested of local jurisdiction). Article III defines the boundaries of the judicial power that Article III courts may exercise. See National Mut. Ins. Co. v. Tidewater Transfer Co., 337 U.S. 582, 615, 645, 655 (1949) (concurring and dissenting opinions) (six Justices rejected proposition that Congress could freely expand Article III judicial power using its Article I powers); see also Hodgson v. Bowerbank, 9 U.S. (5 Cranch) 303, 304 (1809) (Article III jurisdiction may not be extended beyond Article's express limits).

6. Whalen v. United States, 445 U.S. 684, 687 (1980) (acts of Congress affecting only the District equal to other federal laws); Pernell v. Southall Realty, 416 U.S. 363, 368 (1974) (same).

7. E.g., Goode v. Markley, 603 F.2d 973, 976 (D.C. Cir. 1979), cert. denied, 444 U.S. 1083 (1980); Milhouse v. Levi, 548 F.2d 357, 360 n.6 (D.C. Cir. 1976); United States v. Greene, 489 F.2d 1145, 1150 (D.C. Cir. 1973), cert. denied, 419 U.S. 977 (1974); United States v. Williams, 28 F. Cas. 647, 658 (C.C.D.C. 1833) (No. 16,712); United States v. Hammond, 26 F. Cas. 96, 96 (C.C.D.C. 1801) (No. 15,293).

8. Article III provides: "The judicial Power shall extend to all Cases, in Law and Equity, arising under this Constitution [and] the Laws of the United States . . . "U.S. CoNST. art. III, § 2, cl. 1. See Whalen v. United States, 445 U.S. 684, 687 (1980) (D.C. Code "certainly come[s] within this Court's Art. III jurisdiction"); Pernell v. Southall Realty, 416 U.S. 363, 368 (1974) (similar); National Mut. Ins. Co. v. Tidewater Transfer Co., 337 U.S. 582, 650 (1949) (Frankfurter, J., dissenting) (whenever Congress creates "some right for the inhabitants of the District, it could choose to provide for the enforcement of that right in any court of the United States, because the case would be one arising under 'the Laws of the United States" "). Congress has not conferred jurisdiction on the District's Article III courts to hear D.C. Code offenses through an amendment to the Judiciary Act, 28 U.S.C., the normal route of conferring federal question jurisdiction. Instead, it amended the Judiciary Act to exclude D.C. Code causes of action from federal question jurisdiction. 28 U.S.C. $\$ 1364$ (Supp. V 1981) (formerly codified at 28 U.S.C. $\$ 1363$ (1976)).

In general, "[a] suit arises under the law that creates the cause of action," American Well Works Co. v. Layne \& Bowler Co., 241 U.S. 257, 260 (1916), and therefore D.C. Code offenses tried in federal court by virtue of the operation of $\$ 11-502(3)$ arise under D.C. Code substantive criminal provisions, not under the jurisdictional statute. See The Propeller Genesee Chief v. Fitzhugh, 53 U.S. (12 How.) 443, 452 (1852) (Congress cannot circumvent limitations of Article III by enacting purely jurisdictional statute under its Article I powers, and base federal question jurisdiction solely on that statute); Note, Subject Matter Jurisdiction and the Foreign Sovereign Immunities Act of 1976, 68 VA. L. REV. 893, 903 (1982) (constitutional limitation on "arising under" jurisdiction is that "a case may 
over D.C. Code prosecutions may be justified because the United States is named as party plaintiff in those prosecutions: D.C. Code offenses are prosecuted by the United States Attorney in the name of the United States. ${ }^{9}$ Third, local offenses may be considered pendent claims when joined in one indictment with federal charges and tried in federal court. ${ }^{10}$

The Note argues that Congress' exercise of its power under the Constitution to create local law for the District ${ }^{11}$ should not be considered an exercise of its national legislative capacity. Rather, Congress acts as a state-like sovereign when enacting local law. ${ }^{12}$ D.C. Code matters, ${ }^{13}$ therefore, do not "arise under" the "laws of the United States"14 and

not arise under a law enacted pursuant to Congress' power to regulate the federal courts or its power to create federal jurisdiction").

In addition, federal jurisdiction "may not be invoked where the right asserted is non-federal, merely because the plaintiff's right to sue is derived from federal law . . . The federal nature of the right to be established is decisive-not the source of the authority to establish it." Puerto Rico v. Russell \& Co., 288 U.S. 476, 483 (1933); see also Keaukaha-Panaewa Community Ass'n v. Hawaiian Homes Comm'n, 588 F.2d 1216, 1226-27 (9th Cir. 1978) (nature rather than source of claim determines whether right can be litigated in federal court; Hawaiian law enacted pre-statehood by Congress not cognizable post-statehood in federal court), cert. denied, 444 U.S. 826 (1979). Uncertainty should be resolved against extending federal jurisdiction, Romero v. International Terminal Operating Co., 358 U.S. 354, 379 (1959), particularly when local courts can give effective relief.

9. U.S. CONST. art. III, $\S 2$, cl. 1 ("The judicial Power shall extend . . . to Controversies to which the United States shall be a Party ....").

10. The federal courts in the District have interpreted $\$ 11-502(3)$ by analogy to civil pendent jurisdiction. United States v. Shepard, 515 F.2d 1324, 1331 (D.C. Cir. 1975); United States v. Kember, 487 F. Supp. 1340, 1342 (D.D.C.), aff'd, 648 F.2d 1354 (D.C. Cir. 1980); see Financial Gen. Bankshares, Inc. v. Metzger, 680 F.2d 768, $773-74$ n.9 (D.C. Cir. 1982).

11. U.S. CONST. art. I, $\S 8$, cl. 17 ("Congress shall have power . . . to exercise exclusive legislation in all cases whatsoever over [the] District. . .."); see State of Md., Act of Dec. 19, 1791, ch. 45, $\S 2$ (codified at 2 LAWS OF MARYLAND 327 (W. Kilty ed. 1800)) (ceding present District territory to United States).

12. The D.C. Code was enacted under Congress' power to act as the state legislature for the District. Palmore v. United States, 411 U.S. 389, $397-98$ (1973); District of Columbia v. John R. Thompson Co., 346 U.S. 100, 108 (1953); see Capital Traction Co. v. Hof, 174 U.S. 1, 5 (1899) (Congress "may exercise within the District all legislative powers that the legislature of a State might within the State"); Hodgkin, The Constitutional Status of the District of Columbia, 25 POL. SCI. Q. 257, 260 (1910); Comment, Palmore v. United States: The Interrelationship of Article I and Article III of the Constitution, 23 AM. U.L. REv. 119, 140-44 (1973). The D.C. Code is equivalent to a state code. Key v. Doyle, 434 U.S. 59, 68 n.13 (1977). Congress may exercise local legislative authority despite the lack of congressional representation for the District. See Heald v. District of Columbia, 259 U.S. 114, 124 (1922) (upholding taxation without representation). District residents do vote in presidential elections, however, U.S. CONST. amend. XXIII, and elect a nonvoting delegate to the House of Representatives, D.C. CODE ANN. § 1-401 (1981).

13. Congress indicates its intent to create laws of exclusively local application by enacting such legislation as part of the D.C. Code. In Key v. Doyle, 434 U.S. 59 (1977), the Supreme Court stated:

It is more the nature of the D.C. Code than its limited geographical impact that distinguishes it from other federal statutes. Unlike most congressional enactments, the Code is a comprehensive set of laws equivalent to those enacted by state and local governments having plenary power to legislate for the general welfare of their citizens.

Id. at 68 n.18; see United States v. McDonald, 481 F.2d 513, 522 n.24 (D.C. Cir. 1973).

14. Palmore v. United States, 290 A.2d 573, 578-80 (D.C. 1972) (D.C. Code laws not laws of United States requiring Article III judge), aff'd, 411 U.S. 389 (1973); see Katz, Federal Legislative Courts, 43 HARV. L. REV. 894, 902-03 (1930) ("much of the litigation in the territories and in the District falls outside of the categories of cases embraced within the federal 'judicial power' as defined in Article III"); Comment, supra note 12, at 144 (congressionally enacted D.C. Code provisions "not 
D.C. Code offenses are crimes against the District of Columbia, not against the United States. ${ }^{15}$ Since the real party in interest in local prosecutions is the District of Columbia, in prosecuting local crimes the District's United States Attorney acts not in his capacity as a federal officer, but in a local capacity. ${ }^{16}$ As a result, the judicial power of Article III should not normally extend to causes of action under the D.C. Code.

Pendent jurisdiction, the third possible basis for federal court jurisdiction over D.C. Gode offenses, is the only one justifiable under the Constitution. In addition, only the pendent jurisdiction justification for federal jurisdiction comports with congressional intent in separating federal and local spheres in the District. ${ }^{17}$ The exercise of pendent jurisdiction in the

part of the laws of the United States requiring article III court adjudication"); see also American Sec. \& Trust Co. v. Commissioners of the District of Columbia, 224 U.S. 491, 494-95 (1912) (D.C. Code statute not "law of the United States" for purposes of Supreme Court review), cited with approval in Key v. Doyle, 434 U.S. 59, 62 n.5 (1977); Spivey v. Barry, 665 F.2d 1222, 1227 n.14 (D.C. Cir. 1981) (no federal question jurisdiction under District laws); Thomas v. Barry, 543 F. Supp. 801, 804 (D.D.C. 1982) (same); Keyes v. Madsen, 179 F.2d 40, 43 (D.C. Cir. 1949) (D.C. Code provision not "Act of Cengress" within meaning of 28 U.S.C. $\$ 2403$ (1976) (requiring certification to U.S. Attorney General of cases in which "the constitutionality of any Act of Congress affecting the public interest is drawn in question")), cert. denied, 339 U.S. 928 (1950); Herian v. United States, 363 F. Supp. 287, 290 (D.D.C. 1973) (District law not "Act of Congress" for district court jurisdiction under 28 U.S.C. $\S 1345$ (1976)); 28 U.S.C. $§ 1364$ (Supp. V 1981) (formerly codified at 28 U.S.C. $\S 1363$ (1976)) (D.C. Code provisions not "Acts of Congress" or "laws of the United States" for district court jurisdiction). Cases arising under the laws of the territories are comparable to those arising under District laws. See District of Columbia v. John R. Thompson Co., 346 U.S. 100, 105 (1953) (similarity of Congress' constitutional powers over District and territories); Grant v. Cooke, 7 D.C. (2 Mackcy) 165, 200-01 (1871) (structure of 1871 government created for the District (similar to today's Home Rule structure) parallels that of territories); Hodgkin, supra note 12, at 267 (similarity between District and territorial governments). For analogous reasons, therefore, there is no federal question jurisdiction over local territorial Jaw. Territory of Guam v. Olsen, 431 U.S. 195, 199 n.7, 203 (1977) (Guam law); see Calero-Toledo v. Pearson Yacht Leasing Co., 416 U.S. 663, 675 (1974) (Puerto Rico statutes are "state statutes" for purposes of Three-Judge Court Act, 28 U.S.C. $\$ 2281$ (repealed 1976)). Like the District, the territories have no voting representation in Congress. See Leibowitz, United States Federalism: The States and the Territories, 28 AM. U.L. REV. 449, 451 (1979). In addition, Congress reserves power to annul territorial legislature legislation, see National Bank v. County of Yankton, 101 U.S. 129, 133 (1880); 48 U.S.C. $\$ \S 14050,1574$ (c) (1976) (annulment power over Virgin Islands legislature's acts); id. $\$ 1423$ i (annulment power over Guam legislature's acts); Leibowitz, supra, at 452, just as it may annul D.C. Council legislation, see infra note 17. In Harris v. Rosario, 446 U.S. 651, 651-52 (1980), the Court upheld a lower level of federal welfare benefits for Puerto Rico than for states, finding a rational basis for the difference in Puerto Ricans' freedom from federal income tax. District residents, however, are taxed by the federal government at the same rate as state residents.

15. Davis v. United States, 397 A.2d 951, 955 (D.C. 1979) (Federal Probation Act not applicable to D.C. Code offenders because they do not commit "offenses against the United States"); Sanker v. United States, 374 A.2d 304, 306-09 (D.C. 1977) (same).

16. McCall v. Swain, 510 F.2d 167, 180 \& n.34 (D.C. Cir. 1975) (when U.S. Attorney General acts pursuant to order of local court, he probably acts in nonfederal capacity, just as state officials executing federal court orders are considered "federal officers"); Borders v. Reagan, 518 F. Supp. 250, 258 (D.D.C. 1981) (dictum) (federal employee not an "officer of the United States" when execution of his duties involves no nexus with federal law); see also 48 U.S.C. \$1617 (1976) (Virgin Islands U.S. Attorney acts in dual capacity, prosecuting both offenses against United States in name of United States, and offenses against Virgin Islands in name of Virgin Islands' local government).

17. Congress manifested this intent in two separate Acts. In the District of Columbia Court Reform and Criminal Procedure Act of 1970, Pub. L. No. 91-358, 84 Stat. 473 (1970) [hereinafter cited 
criminal context, however, promotes jury hostility and creates arbitrary differences in trial outcomes among similarly situated offenders. In civil pendent jurisdiction cases, the trial judge must supervise litigants to prevent abuse. Due to the special characteristics of criminal cases, however, the supervisory powers of the trial judge are severely curtailed. For this reason, pendent jurisdiction is not an appropriate concept to import to the criminal context. The Note concludes that the District's federal courts should be divested of the section 11-502(3) vestige of local jurisdiction.

\section{Nonfederal Nature of the D.C. Code}

Congress' power of local legislation over the District of Columbia is wholly different from its national legislative powers, and precludes the definition of the D.C. Code as "federal law." In addition, the description of laws of exclusively local application in the District as "federal," and therefore as within the "arising under" jurisdiction of Article III courts, undermines a desirable uniformity in the interpretation of District law. This description also is at odds with Congress' overriding intent in the

as "Court Reform Act"] (codified at D.C. CODE ANN. tit. 11 (1981)), Congress created two separate court systems in the District. See M.A.P. v. Ryan, 285 A.2d 310, 313 (D.C. 1971) (in distributing judicial power in the District, Court Reform Act allotted to each system its own sphere, making neither subservient to the other). In the 1973 District of Columbia Self-Government and Governmental Reorganization Act, Pub. L. No. 93-198, 87 Stat. 774 (1973) [hereinafter cited as "Home Rule Act"] (codifed at scattered sections of the D.C. Code), Congress created a local state-like entity in the District, delegating its local legislative power to a Mayor, D.C. CODE ANN. $\$ \S 1-241,1-242$ (1981), and to a 13-member Council, id. \$1-221. The Council's powers became "as broad as those of Congress." Firemen's Ins. Co. v. Washington, 483 F.2d 1323, 1328 (D.C. Cir. 1973). Included in this delegation was the power to classify certain acts as crimes. District of Columbia v. Sullivan, 436 A.2d 364, 366 (D.C. 1981). Congress did place several restrictions on the Council's legislative authority, see D.C. CODE ANN. $\S 1-233$ (a) (1981), but in general the Council's legislative powers are limited just as are those of the states, by Article I, $\S 10$ of the U.S. Constitution, D.C. CODE ANN. $\$ 1-204$ (1981), see Grant v. Cooke, 7 D.C. (2 Mackey) 165, 196-97 (1871) (identical prohibition on acts of 1871 D.C. Legislative Assembly interpreted by Court as limitation "appropriate only to States, or governments similar to them"); see also Firemen's Ins. Co. v. Washington, 483 F.2d at 1328 (District "akin to a state").

Despite this broad delegation, Congress retained "ultimate legislative authority," D.C. CODE ANN. $\S 1-201$ (a) (1981), and a legislative veto power, D.C. CODE ANN. § 1-233(c) (1981 \& Supp. 1982). (The constitutionality of this veto power has been called into question by the Supreme Court's recent opinion in Immigration \& Naturalization Serv. v. Chadha, 103 S. Ct. 2764, 2787-88 (1983).). Congress also reserved the power to legislate affirmatively for the District. D.C. CODE ANN. § 1-206 (1981). Any act passed by the Council and approved by the Mayor must be submitted to Congress; a majority of both the House and the Senate may nullify the measure within thirty calendar days. D.C. CODE ANN. § 1-233(c)(1) (1981 \& Supp. 1982); see D.C. CODE ANN. § 1-233(c)(2) (1981) (majority of either House sufficient to veto measure dealing with criminal law or procedure). In judging D.C. Council actions, the House District Committee determines whether the action violates the Constitution or a clear federal interest, or exceeds power granted the Council in the Home Rule Act. See 127 CONG. REC. H6741 (daily ed. Oct. 1, 1981) (statement of Rep. McKinney). For example, the House of Representatives exercised its supervisory power over Council legislation by vetoing a proposed Sexual Assault Reform Act, D.C. Act 4-69. H. R. Res. 208, 97th Cong., 2d Sess., 127 CONG. REC. H6762 (daily ed. Oct. 1, 1981). For the history of cession and of the various District governments, see Franchino, The Constitutionality of Home Rule and National Representation for the District of Columbia (pt. 1), 46 GEO. L.J. 207, 208-210, 214-23 (1957-1958). 
1970 Court Reform and 1973 Home Rule Acts ${ }^{18}$ to create autonomous federal and local legal frameworks in the District and to fashion a new federal-local court relationship analogous to that existing in the states. Finally, this "federal" definition, and the consequent description of D.C. Code offenses as "crimes against the United States," cannot be reconciled with the actual jurisdiction conferred by Congress upon the District's courts in the Court Reform Act. Accordingly, local criminal offenses should be redefined as "crimes against the District of Columbia."

\section{A. Hybrid Congressional Power}

Under Article I, section 8, clause 17 of the Constitution, Congress is granted the power of "exclusive legislation in all cases" in the District. ${ }^{19}$ The courts have interpreted this power both as wholly national and as "plenary" in character. ${ }^{20}$ This interpretation has justified the extension to the District of legislation enacted under Congress' other Article I powers that exceeds Congress' powers as applied to states. ${ }^{21}$ The supposed "plenary" nature of this power in addition has given some courts sufficient justification to apply laws codified in the D.G. Code to federal matters in the District, ${ }^{22}$ even though legislation of this type and effect could not justifiably be enacted by a state legislature.

At the heart of these cases is a failure to recognize that clause 17 grants

18. See supra note 17 (discussing the two Acts).

19. U.S. CONST. art. I, § 8, cl. 17.

20. Chief Justice Marshall, for example, maintained that the only "safe and clear rule" that may be articulated in determining the status of Congress' clause 17 power relative to its other enumerated Article I powers is that all such powers are equal. Cohens v. Virginia, 19 U.S. (6 Wheat.) 264, 364, 424, 426 (1821) (all laws passed by Congress under its Article I powers, including clause 17, are "laws of the United States"); see Northern Pipeline Constr. Co. v. Marathon Pipe Line Co., 102 S. Ct. 2858, 2888 n.8 (1982) (White, J., dissenting) (all Article I powers are equal); O'Donoghue v. United States, 289 U.S. 516, $539-40$ (1933) (all Article I powers are for national purposes), cited with approval in National Mut. Ins. Co. v. Tidewater Transfer Co., 337 U.S. 582, 601 (1949); Kendall v. United States ex rel. Stokes, 37 U.S. (12 Pet.) 524, 619 (1838) (Congress has full plenary power); Neild v. District of Columbia, 110 F.2d 246, 250-51 (D.C. Cir. 1940) (Congress acts as legislature of national character when legislating for the District); United States v. Williams, 28 F. Cas. 647, 65558 (C.C.D.C. 1833) (No. 16,712) (no distinction between federal and municipal powers in the District); O'Donoghue, The Power of Congress to Tax in Respect to the District of Columbia, 31 GEO. L.J. 146, 159 (1943) ("Congress is never a state legislature but always and necessarily the national legislature and it is only in this capacity that it can ever act.").

21. See Employers' Liability Cases, 207 U.S. 463, 500 (1908) (Congress' plenary power over District justifies its application to District of measures that would violate commerce clause if applied to states); Hyde v. Southern Ry., 31 App. D.C. 466, 472-73 (1908) (same); see also Neild v. District of Columbia, 110 F.2d 246, 251 (D.C. Cir. 1940) (commerce clause no limitation on Congress' local legislative powers, only bar to state legislation). Clause 17 also was used to justify interference with federal functions of the District's courts. In Federal Radio Comm'n v. General Elec. Co., 281 U.S. 464, 466, 468 (1930), and in Postum Cereal v. California Fig Nut Co., 272 U.S. 693, 699-700 (1927), the Court noted that Congress had empowered the District's courts to oversee factfinding of federal agencies, despite the fact that this function would violate the separation of powers principle if vested in Article III courts.

22. See infra p. 321. 
three different types of power to Congress: first, the power to extend laws of nationwide application to the District; ${ }^{23}$ second, the power to protect national interests there; and third, the power to enact state-like local laws governing District residents. Clause 17 grants hybrid powers to Congress, and thus is a unique source of congressional authority, distinct from Congress' other section 8 powers of purely national scope. ${ }^{24}$ When Congress legislates under its other section 8 powers, it creates "laws of the United States" falling within the Article III "arising under" jurisdiction, which it may choose to enforce in Article III courts. Congress may also create "laws of the United States" under clause 17, and does so when it promulgates rules to protect the functioning of the national government.

A major component of Congress' clause 17 power, however, is the authority to enact local laws for the District. Two factors differentiate between the types of laws that may be enacted under clause 17. First, as to subject matter, the scope of local laws may be much greater than the "laws of the United States." As the Supreme Court has noted, the enactment of the D.C. Code "would exceed [Congress'] powers . . . in the context of national legislation enacted under other powers delegated to it under Art. I, § 8."25 Second, local laws, unlike federal laws, must be confined in application to a limited geographical area. Congress itself has recognized the intuitive distinction between federal and local laws, by codifying the D.G. Code separately from the U.S. Code. Even as a matter of history, the two types of laws are distinct: The first local laws for the District were the laws of the ceding states, which Congress adopted in toto, ${ }^{26}$ only gradually reshaping them over the years to meet the changing

23. Palmore v. United States, 411 U.S. 389, 397 (1973).

24. See infra note 29.

25. Palmore v. United States, 411 U.S. 389, 398 (1973); see supra notes 12, 13.

26. From 1790 to 1801 , the District continued to be governed by the laws of the ceding states. Act of July 16, 1790, ch. $28, \S 1,1$ Stat. 130; see 13 STATS. AT LARGE OF VIRGINIA ch. 32, at 44 (W. Hening ed. 1823); 2 LAWS OF MARYLAND ch. 45, $\S 2$, at 327 (W. Kilty ed. 1800). In 1801, Congress reenacted those state laws previously applicable to the area ceded, Act of Feb. 27, 1801, ch. 56, $\S 1,2$ Stat. 103 (codified in REVISED STATUTES OF THE UNITED STATES RELATING TO THE DISTRIGT OF COLUMBIA $\S 92$ (1875)), and from 1801 to 1871 the District was "governed for the most part under the laws of Maryland and Virginia as they existed at the time of cession." Byrd, District of Columbia "Home Rule," 16 AM. U.L. REV. 254, 258 (1967). Maryland statutes were freely quoted in all compilations of laws before the first D.C. Code, of 1901, was enacted, and the 1875 edition of D.C. statutes provided that all offenses not therein defined would continue to be "punished as provided by laws in force in the District." REVISED STATUTES OF THE UNITED STATES RELATING TO THE DISTRICT OF COLUMBIA $\$ 1146$ (1875). Congress also continued to distinguish between local and federal offenses. See Act of June 17, 1870, ch. 62, § 1, 16 Stat. 153 (vesting jurisdiction over both "offences against the United States" as well as "offences against any of the ... laws of the levy court [local legislative court] of the County of Washington" in a Police Court); see also REviSED STATUTES OF THE UNITED STATES RELATING TO THE DISTRICT OF COLUMBIA § 1101 (1875) (distinguishing persons convicted under "laws of the United States" from those convicted under laws "of the District," providing that both types of offenders could be housed in the District's prison). This latter distinction continues today in the differentiation for fiscal purposes between D.C. Code offenders, sentenced in local or federal court, and U.S. Code offenders. The U.S. reimburses the District government for U.S. 
needs of the District. In addition, Congress never required that these laws be interpreted by Article III courts. Upon cession, Congress created statelike courts of general jurisdiction ${ }^{27}$ to enforce the local laws, investing these courts with the same civil and criminal common law powers enjoyed by the state courts prior to cession. ${ }^{28}$ All of these factors point to one

offenders housed in the District's Lorton, Virginia, prison, D.C. CODE ANN. § 24-446 (1981), while the District government reimburses the U.S. for costs of housing D.C. Code offenders in federal institutions, D.C. CODE ANN. § 24-424 (1981).

27. The original courts of general jurisdiction for the District, the circuit court for the District of Columbia, created by the Act of Feb. 27, 1801, ch. 15, $\S 3,2$ Stat. 103, 105, and its successor, the supreme court, see Act of Mar. 3, 1863, ch. 91, § 1, 12 Stat. 762, 762-63, initially were not defined as established under Article III, United States v. Burroughs, 289 U.S. 159, 163 (1933). Since the major function of these courts was to exercise general, state court-like jurisdiction, it was believed that they could not be so established, even though they sat as "courts of the United States" exercising federal jurisdiction in special terms, and their judges were tenured. See Act of Apr. 29, 1802, ch. 31, $\$ 24,2$ Stat. 156, 166 (circuit court to exercise power of U.S. district court in special term); Act of Mar. 3, 1863, ch. 91, § 3, 12 Stat. 762, 763 (same, for supreme court). By virtue of their special terms, however, these courts were permitted to exercise the same powers as Article III "courts of the United States." Claiborne-Annapolis Ferry Co. v. United States, 285 U.S. 382, 391 (1932) (District's court may set aside federal agency (ICC) orders sitting as court of the United States); Federal Trade Comm'n v. Klesner, 274 U.S. 145, 154, 156, 158 (1927) (because of complete parallelism between jurisdiction of the District's courts and of Article III courts, the District's court may set aside federal agency (FTC) order). These extended powers may have influenced the Supreme Court's decision in O'Donoghue v. United States, 289 U.S. 516, 538-40, 546 (1933), that Congress could not continue to deny District residents an Article III forum, and, accordingly, its courts must be considered Article III courts. See Act of June 7, 1934, ch. 426, 48 Stat. 926 (D.C. Court of Appeals changed to United States Court of Appeals for the District of Columbia); Act of June 25, 1936, ch. 804, 49 Stat. 1921 (D.C. Supreme Court became United States District Court for the District of Columbia); Act of Dec. 29,1942 , ch. $835, \S 1$ (d), 56 Stat. 1094 (District's courts became a federal judicial circuit). The District's new Article III courts continued to hear nonfederal question matters arising under District law, and to exercise administrative and advisory functions-forbidden to other Article III courts for separation of powers reasons-previously vested in the District's courts by virtue of their non-Article III status. The O'Donoghue opinion therefore created an anomaly: For the first time, Article III courts would exercise non-Article III functions. The conceptual difficulty of justifying Article III court exercise of these other types of jurisdiction has contributed to the confusion found in a series of extremely divided Supreme Court decisions: the 3-2-2-2 opinions in National Mut. Ins. Co. v. Tidewater Transfer Co., 337 U.S. 582 (1949), the 3-2-2 opinions in Glidden Co. v. Zdanok, 370 U.S. 530 (1962), and the 4-2-3 opinions in Northern Pipeline Constr. Co. v. Marathon Pipe Line Co., 102 S. Ct. 2858 (1982). Attempting to solve the problem, the Court has created an unclear division between "Article I" (or "legislative") and "Article III" courts. See infra note 82. In the Court Reform Act, Congress resolved the issue in the District by creating federal courts identical in jurisdiction to all other Article III courts, see supra note 5, and by restoring the local courts of the District to a position similar to the one they occupied prior to cession, as quasi-state courts of general jurisdiction, without any attributes of Article III courts. D.C. CODE ANN. § 11-921(a) (1981) (civil jurisdiction); id. § 11923(b)(1) (criminal jurisdiction). See Palmore v. United States, 411 U.S. 389, 392 n.2 (1973) (Congress "invested the local courts with jurisdiction equivalent to that exercised by state courts"); H.R. REP. NO. 907, 91st Cong., 2d Sess. 35 (1970) (same). Local judges do not have tenure guarantees, D.C. CODE ANN. \$§ 11-1523, 11-1526 (1981), and therefore local courts are not "courts of the United States" as defined in 28 U.S.C. \$ 451 (1976) (courts of United States are those whose judges are entitled to hold office during good behavior).

28. The local District courts possess the common law powers of the ceding states' courts. Kendall v. United States, 37 U.S. (12 Pet.) 524, 614, 620-21 (1838); Pang-Tsu Mow v. Republic of China, 201 F.2d 195, 198 (D.C. Cir. 1952), cert. denied, 345 U.S. 925 (1953). The present D.C. Code continues in force Maryland common law, D.C. CODE ANN. \$ 49-301 (1981), not only that law as it was construed in Maryland at the time of cession, but also the evolving common law, Linkins $v$. Protestant Episcopal Cathedral Found., 187 F.2d 357, 360-61 (D.C. Cir. 1950). In interpreting this common law, the District's courts use Maryland decisions. Watkins v. Rives, 125 F.2d 33, 35 (D.C. 
conclusion: "laws of the United States" and the laws of the District of Columbia should not be equated, ${ }^{29}$ and accordingly, the Article III judicial power does not normally encompass District local law.

The limitations upon Congress' exercise of local powers never have been delineated with precision. As a matter of symmetry, however, since Congress may enact local laws for the District that exceed its normal powers under other parts of section $8,{ }^{30}$ there is no structural reason why the limitations upon Congress' exercise of its local legislative function should be identical to those governing its exercise of national powers. In fact, District residents are best protected by requiring instead that Congress be bound in the exercise of its local legislative capacity by constitutional restrictions similar to those that govern a state's dealings with its citizens. $^{31}$

Cir. 1941); Gerace v. Liberty Mut. Ins. Co., 264 F. Supp. 95, 97 (D.D.C. 1966). The District's courts may try offenders for common law crimes. United States v. Davis, 71 F. Supp. 749, 750 (D.D.C. 1947), rev'd on other grounds, 167 F.2d 228 (D.C. Cir.), cert. denied, 334 U.S. 849 (1948). By contrast, there are no common law offenses against the United States, only offenses defined by statute. United States v. Hudson \& Goodwin, 11 U.S. (7 Cranch) 32, 34 (1812).

29. Several cases have recognized this distinction. In American Sec. \& Trust Co. v. Rudolph, 38 App. D.C. 32, 45 (1912), the court described Congress' federal and local powers under clause 17 as "two distinct classes of legislative powers." Under one, Congress enacts "laws that govern throughout the United States." Under the second, Congress possesses "special legislative powers to the full extent possessed by" the ceding states. These powers, exercised in the D.C. Code, "are local in their nature and purpose, and expressly limited to the boundaries of the District. They are not laws of the United States . . . "See Northern Pipeline Constr. Co. v. Marathon Pipe Line Co., 102 S. Ct. 2858, 2874 (1982) ("powers granted under that clause are obviously different in kind from the other broad powers conferred on Congress").

30. See supra p. 298.

31. In Hamilton Nat'l Bank v. District of Columbia, 176 F.2d 624 (D.C. Cir.), cert. denied, 338 U.S. 891 (1949), the court concluded:

[T] he due process of the Fifth Amendment should include or imply for the inhabitants of the

District of Columbia equal protection of the laws enacted by Congress as the local legislature of the District. It is unthinkable that Congress, enacting statutes applicable only in this jurisdiction, does not violate the due process clause of the Fifth Amendment if it denies the people of this District equal protection of the laws, just as a state legislature violates the "equal protection" clause of the Fourteenth Amendment if it does the same thing.

Id. at 630. Instead of adopting this restricted definition of Fifth Amendment "equal protection," the Supreme Court in Bolling v. Sharpe, 347 U.S. 497, 500 (1954) (holding invalid statute authorizing racial segregation in District schools), stated that the due process clause of the Fifth Amendment embodies equal protection principles applicable to all Congressionally enacted law. The result reached in Bolling did not require such a sweeping pronouncement, for the statute in question, like the statute at issue in Hamilton National Bank, applied only to District of Columbia residents.

A similar unwarranted expansion of congressional authority took place in the field of eminent domain. In its first opinion delineating the bounds of Congress' power to appropriate private property, the Supreme Court limited the permissible objectives of such appropriation to those that fall within the delegated enumerated powers of the federal government. Kohl v. United States, 91 U.S. 367, 372 (1876). A few years later, the Court held that in the District, Congress is not so limited in its takings power, but may appropriate property for any public use justifiable under traditional state police power. Shoemaker v. United States, 147 U.S. 282, 298 (1893) (upholding condemnation of private property in District for use as public park); see Berman v. Parker, 348 U.S. 26 (1954). This broad approach to Congress' eminent domain power is now applied not only in the District, where it is supported by Congress' state-like authority, but also in the states, where it has no such support. The Supreme Court now will not place any limitation upon the types of "public uses" for which Congress 
The national powers of Congress contained in clause 17 also are subject to constitutional restraints. When Congress extends national legislation to the District, its actions are limited by the constitutional rights of District residents, which predate congressional sovereignty over the area. These rights were extended while the District still was a part of two states of the Union, and were not abrogated by its cession to the United States. ${ }^{32}$ The rights of District residents would be secured by requiring Congress to be bound, when extending national law to the District, by the standard of uniformity that governs its relationship with the states. ${ }^{33}$ Congress, and

may appropriate property. See United States ex rel. Tennessee Valley Auth. v. Welch, 327 U.S. 546, 551 (1946) ("it is the function of Congress to decide what type of taking is for a public use," not the function of the Court). As in the case of equal protection, had the Court recognized the distinction between Congress' broad police power in the District, and its restricted enumerated powers elsewhere in the Union, the expansion of Congress' power of eminent domain may well never have occurred.

These results have been made possible by the combined application of two incompatible principles: first, that Congress may exercise the police power of a state in legislating for the District, see supra note 12 , and thus has much broader powers there than in any other part of United States, see Gibbons v. District of Columbia, 116 U.S. 404, 408 (1866) (in legislating for the District, "Congress, like any state legislature [is] unrestricted by constitutional provisions"), and second, that all laws enacted for the District must be considered "laws of the United States," see supra notes 6, 7. The second principle bootstraps upon the first, and the outcome is the unwarranted expansion of congressional power in the fifty states.

32. In Downes v. Bidwell, 182 U.S. 244, 260-61 (1901), the Court stated that when the District was part of the ceding states, the Constitution "attached to it irrevocably." Cession did not take the District "out of the United States or from under the aegis of the Constitution" since neither party to the cession contract "had ever consented to that construction of the cession." Since a pre-cession unconstitutional act affecting its inhabitants would have been void, "Congress could not do indirectly by carving out the District what it could not do directly." See O'Donoghue v. United States, 289 U.S. 516, 540 (1933) (District "not taken out of the Union by cession. Prior thereto its inhabitants were entitled to all the rights, guaranties, and immunities of the Constitution, among which was the right to have their cases arising under the Constitution heard and determined by federal courts created under . . . Art. III."); see also National Mut. Ins. Co. v. Tidewater Transfer Co., 337 U.S. 582, 62021 n.14 (1949) (Rutledge, J., concurring) (list of applicable constitutional guarantees); Hodgkin, supra note 12, at 262 (civil rights guarantees of the Constitution apply to the District, including guarantee of republican government).

33. Chief Justice Marshall may have approved of the view that in extending national law to the District, Congress should be bound by constitutional restrictions that govern its dealings with states. In Hepburn \& Dundas v. Ellzey, 6 U.S. (2 Cranch) 445, 453 (1805) (District not a state within original meaning of Constitution; therefore Article III diversity jurisdiction between citizens of different states may not be extended to District residents until Congress so legislates), he implied that clause 17 conveyed to Congress a power to redefine the word "state" as used in Article III to include the District. Justice Marshall thus seemed to sanction a limited use of Article I powers to expand, only for definitional purposes, the judicial power conveyed by Article III. (Congress did legislate as Justice Marshall suggested, see 28 U.S.C. $\S 1332(\mathrm{~d})$, upheld as constitutional in National Mut. Ins. Co. v. Tidewater Transfer Co., 337 U.S. 382 (1949)). In Loughborough v. Blake, 18 U.S. (5 Wheat.) 317,325 (1820), Justice Marshall again suggested that Congress could use its power of redefinition to expand the meaning of "state" used in Article I, $\S 2$, cl. 3, requiring Congress to apportion direct taxes among the states. In Loughborough, Justice Marshall stated his assumption that "the principle of uniformity, established in the constitution, secures the district from oppression." Id.

Congress always has considered itself empowered to extend constitutional guarantees referring to "states" to the District and to territories, exercising the power of redefinition recognized by Justice Marshall in Hepburn and Loughborough. For example, the interstate rendition clause, art. IV, $\S 2$, cl. 2, refers to "states," but Congress extended its requirements to territories, Act of Feb. 12, 1793, ch. $7, \S 1,1$ Stat. 302. The full faith and credit clause, art. IV, $\S 1$, also refers only to "states," but Congress extended it to courts of territories, Act of Mar. 27, 1804, ch. 56, § 2, 2 Stat. 298, 299. The 
the courts, should not be permitted to circumvent this standard simply by invoking the clause 17 "plenary" power.

Although the boundaries between the various powers conveyed by clause 17 may at times be blurred, the possibility of some ambiguity does not justify a refusal to acknowledge differences in congressional capacity when enacting federal and local law. The federal and local legal frameworks in the District plainly are separate and autonomous, and, accordingly, the description of Congress' power over the District as purely "federal" and of the D.C. Code as "laws of the United States" cannot be justified.

\section{B. Goal of Uniformity}

Local crimes in the District may be defined by three sources of authority: by Congress, by the locally elected District Council, ${ }^{34}$ and by the District's local courts, exercising their criminal common law powers inherited from the courts of Maryland. ${ }^{35}$ Local laws, no matter what their source, should be uniformly construed and applied. If the laws emanating only from the first source, Congress, are considered "federal" and therefore within Article III court "arising under" jurisdiction, arbitrary distinctions in the interpretation of District local law would result.

The needed consistency is possible only if local congressional enactments are treated as local law. It is implausible to interpret District law instead as a uniform body of federal law. The local Court of Appeals has stated that it is "quite unlikely" that the mere act of cession of the District from Maryland transformed Maryland local offenses into general federal offenses. ${ }^{36}$ Further, enactments of Congress and of the Council cannot be

\footnotetext{
Supreme Court held that the full faith and credit clause imposes the same obligations upon the District's courts as it does upon state courts, Loughran v. Loughran, 292 U.S. 216, $227-28$ (1934). Congress extended the full Constitution to the District in 1871, Act of Feb. 21, 1871, ch. 62, § 34, 16 Stat. 419,426 , but did not specify whether it intended just to extend rights of national citizenship to District residents, or to redefine its relationship with the District along the lines of the national-state relationship embodied in the Constitution. In that same Act, Congress also created a state-like territorial government for the District, with an elected Governor (exercising the powers of today's Mayor), and a Legislative Assembly (similar to today's D.C. Council), id. § 2, 16 Stat. 419 (Governor), id. § 5, 16 Stat. 420 (Assembly). This structure lends support to the interpretation that Congress intended to treat the local entity as a state. It is difficult to interpret the Act as merely granting rights of national citizenship, since District residents unquestionably enjoyed those rights prior to 1871. Congress has reinforced this interpretation by defining the District as a state in almost 200 provisions of the U.S. Code. See U.S.C. index (District of Columbia) (1976 \& Supp. V 1981).

34. See supra note 17 (discussing Council authority).

35. See supra note 28.

36. Palmore v. United States, 290 A.2d 573, 579 (D.C. 1972), aff'd, 411 U.S. 389 (1973). See Puerto Rico v. Russell \& Co., 288 U.S. 476, 483 (1933) (act of Puerto Rico legislature presents no federal question, even though authority to maintain suit derives from an Act of Congress); Fraenkl v. Cerecedo Hermanos, 216 U.S. 295, 304 (1910) (order of Puerto Rico military governor not "law of the United States" and therefore not "arising under a law of the United States").
} 
equated by characterizing the latter as a federal instrumentality, fashioning federal rules for the District. Unlike federal agencies, the Council is popularly elected, ${ }^{37}$ and may amend its own "enabling statute," the District Charter ${ }^{38}$ The Council's power extends to all proper subjects of legislation, much like a state legislature, and its powers are limited just as are those of the states, by Article I, section 10 of the United States Constitution. ${ }^{39}$

Finally, the nondelegation doctrine no longer poses a roadblock to uniformity. At one time, courts refused to permit Congress to delegate its power to define local offenses to a local legislature, holding that Congress could not delegate "general" lawmaking power. ${ }^{40}$ The nondelegation rule in turn was used to uphold the characterization of local offenses as crimes against the United States. ${ }^{11}$ The Supreme Court later disapproved this line of cases and ruled that Congress could delegate its power to define local offenses to a local legislative authority. ${ }^{42}$ In so doing, the Court distinguished between Congress' local and national powers, holding that only the former may be delegated and that delegated local power may be as broad as the police power of the states. ${ }^{43}$ In the Home Rule Act, Congress did in fact delegate to the current District local government the power to define local offenses, ${ }^{44}$ and there is little doubt that this delegation is constitutional. ${ }^{45}$ The nondelegation justification for continuing to categorize local offenses as "crimes against the United States" therefore has been removed.

37. See supra note 17 .

38. Amendments to the District Charter must be approved by Congress. D.C. CODE ANN. § 1205(b) (1981).

39. See supra note 17.

40. Fletcher v. United States, 42 App. D.C. 53, 63 (1914); United States v. Cella, 37 App. D.G. 433, 435 (1911), cert. denied, 223 U.S. 728 (1912). In Cella, the court rejected plaintiff's argument that prosecutions under the D.C. Code should be brought in the name of the District of Columbia rather than the United States, basing its holding on the nondelegation doctrine. Since Congress may not delegate the authority to enact local criminal statutes, reasoned the court, the United States must continue to prosecute crimes under those statutes. Now that the nondelegation limitation has been overruled, see infra note 42 , there is no longer any sound rationale for barring the prosecution of local offenses by the real party in interest in local District prosecutions, the District of Columbia.

41. Sec, e.g., Metropolitan R.R. v. District of Columbia, 132 U.S. 1, 9 (1889) (crimes committed in the District are crimes against United States because Congress, not District government, is sovercign there); Franchino, supra note 17, at 231-39 (discussing line of cases); Hodgkin, supra note 12, at 265-67 (same).

42. District of Columbia v. John R. Thompson Co., 346 U.S. 100, 108-10 (1953); see Firemen's Ins. Co. v. Washington, 483 F.2d 1323, 1328 (D.C. Cir. 1973) ("When Congress delegates its police power to the local government, that entity's powers become as broad as those of Congress . . . .").

43. District of Columbia v. John R. Thompson Co., 346 U.S. 100, 105-09 (1953).

44. See supra note 17 (discussing Home Rule Act).

45. Borders v. Reagan, 518 F. Supp. 250, 266 n.23 (D.D.C. 1981). 


\section{Congressional Intent and the Court Reform Act}

Congress implicitly ratified the view of the D.C. Code as a body of nonfederal, state-like law in its restructuring of the court system in the District. It did not make all areas of federal and District law consistent with this approach, however: A few provisions that bear upon the federalstate relationship have not been extended to govern the federal-District one, although they are equally applicable to it.

\section{Analogy to States}

Congress separated federal and local jurisdiction in the District by analogy to the federal-state court system model. It created two types of courts for the District: first, Article III courts equivalent in jurisdiction to federal courts in the fifty states to determine federal matters, ${ }^{46}$ with no federal question jurisdiction over Acts of Congress applicable exclusively to the District of Columbia, ${ }^{47}$ and second, local courts equivalent to state courts of general jurisdiction. ${ }^{48}$ Congress structured the relationship between the federal and local courts to parallel that existing in the fifty states. ${ }^{4 \theta}$ The federal courts have long considered District residents to be state citizens for purposes of federal court diversity jurisdiction; ${ }^{60}$ now the District is defined as a state for federal civil rights jurisdiction ${ }^{\text {s1 }}$ and for removal jurisdiction; ${ }^{\mathbf{2}}$ and District officials can act "under color of state law." Ds D.C. Code statutes are considered "statutes of the District of Columbia" for purposes of federal civil rights statutes;" the local Court of Appeals is defined as the "highest court of a state" for purposes of Supreme Court review; ;5 and the local courts are considered state courts for purposes of removal jurisdiction. ${ }^{56}$

46. See supra note 5 .

47. 28 U.S.C. $\S 1364$ (Supp. V 1981) (formerly codified at 28 U.S.C. $\S 1363$ (1976)).

48. See supra note 27 .

49. H.R. REP. NO. 907, 91st Cong.; 2d Sess. 35 (1970) (jurisdiction of local courts of the District will be "comparable with State courts . . . result[ing] in a Federal-State court system . . . analogous to court systems in the several States"); 116 CONG. REC. 8098 (1970) (statement of Rep. Harsha) (District court system "on a par with systems in the 50 States"); see United States v. Thompson, 452 F.2d 1333, 1342 (D.C. Cir. 1971) ("overriding purpose" of Court Reform Act "to put the District's judicial system on a par with those of the states"), cert. denied, 405 U.S. 998 (1972).

50. 28 U.S.C. $\& 1332$ (d) (1976).

51. 28 U.S.C. $\$ 1343$ (b)(1) (Supp. V 1981).

52. 28 U.S.C. $\$ 1451(2)(1976)$.

53. 42 U.S.C. $\S 1983$ (Supp. V 1981); see Hurd v. Hodge, 334 U.S. 24, 31 (1948) (District included within "State or Territory" of 42 U.S.C. $\$ 1982)$.

54. 28 U.S.C. $\S 1343($ b)(2) (Supp. V 1981).

55. 28 U.S.C. § 1257 (1976); see D.C. CODE ANN. § 11-102 (1981); SUP. CT. R. 54.

56. 28 U.S.C. $\$ 1451$ (1) (1976); see District of Columbia ex rel. John Driggs Co. v. Ranger Constr. Co., 394 F. Supp. 801, 802 (D.D.C. 1974) (Congress intended that District defendants "have a right to removal concomitant with defendants sued in state courts"); see also Johnson v. Robinson, 509 F.2d 395, 398-99 (D.C. Cir. 1974) (local courts treated as state courts for purposes of exhaustion 
The federal and local courts in the District have implemented Congress' expressed intent by fashioning their relationship according to principles of federalism and comity. The local courts have held themselves not bound by decisions of the D.C. Circuit, notwithstanding a federal constitutional basis for those decisions. ${ }^{57}$ The D.C. Circuit has interpreted the Court Reform Act to give local courts in the District "full responsibility for the development of the District's own law," courts must accord the "greatest deference" to local court decisions. ${ }^{58}$ The federal courts have adapted the major guidelines that shape their approach to state law and state courts-the Younger, ${ }^{60}$ Pullman, $^{61}$ and $E_{r i e^{62}}$ doctrines-to their dealings with District of Columbia local law matters.

\section{Remaining Inconsistencies}

Many provisions in the U.S. Code bear on the federal-state relationship, however, and Congress failed to amend some of these to conform to its general scheme for the District of Columbia. Noting Congress' express

of state remedies prior to invocation of federal habeas corpus jurisdiction).

57. M.A.P. v. Ryan, 285 A.2d 310, 312-13 (D.C. 1971); see Bethea v. United States, 365 A.2d 64, 71 (D.C. 1976), cert. denied, 433 U.S. 911 (1977).

58. Steorts v. American Airlines, Inc., 647 F.2d 194, 196 (D.C. Cir. 1981).

59. McCall v. Swain, 510 F.2d 167, 173 (D.C. Cir. 1975).

60. Younger v. Harris, 401 U.S. 37 (1971) (federal court must dismiss injunction action challenging state law under which plaintiff concurrently prosecuted in state court); see Rieser v. District of Columbia, 580 F.2d 647, 657 (D.C. Cir. 1978) (Younger doctrine limit on federal jurisdiction designed to protect very type of court system created in the District with pervasive local responsibilities). But see Halleck v. Berliner, 427 F. Supp. 1225, 1239 (D.D.C. 1977) (since Younger doctrine based on principles of federalism, it does not "apply with the same force" in the District).

61. Railroad Comm'n v. Pullman Co., 312 U.S. 496 (1941) (abstention doctrine); see Thomas v. Barry, 543 F. Supp. 801, 804 (D.D.C. 1982) (federal court should abstain from deciding matters of District law and public policy); Association of Court Reporters v. Superior Court, 424 F. Supp. 90, 96 (D.D.C. 1976) (same); see also Sullivan v. Murphy, 478 F.2d 938, 962 n.35 (D.C. Cir.) (if Congress intended to pattern federal-local court relationship on federal-state one, then doctrine does apply), cert. denied, 414 U.S. 880 (1973). But see Halleck v. Berliner, 427 F. Supp. 1225, 1239 (D.D.C. 1977) (since Pullman based on federalism principles, it does not apply with equal force in the District as in states).

62. Erie R.R. v. Tompkins, 304 U.S. 64 (1938) (federal courts in diversity cases follow state common law). The District is accorded full equality with states for diversity jurisdiction purposes, see 28 U.S.C. $\$ 1332$ (d) (1976), but 28 U.S.C. $\$ 1652$ (1976), requiring federal courts in diversity to use state law as rule of decision, does not define the District as a state. Even so, the policy bases for Erie are equally applicable to the District, Anchorage-Hynning \& Co. v. Moringiello, 697 F.2d 356, 360 61 (D.C. Cir. 1983) (per curiam), and therefore federal court deference and comity principles should substitute for Erie. Lee v. Flintkote Co., 593 F.2d 1275, 1278 n.14 (D.C. Cir. 1979). For this reason the District's federal courts in diversity cases look to the local courts to provide choice of law principles and substantive rules of decision. Semler v. Psychiatric Inst., 575 F.2d 922, 926-31 (D.C. Cir. 1978); see also Fireman's Fund Ins. Co. v. Videfreeze Corp., 540 F.2d 1171, 1174-75 (3d Cir. 1976) (construing Rules of Decision Act to apply to all nonfederal matters; applies Virgin Islands burden of proof rule in diversity case), cert. denied, 429 U.S. 1053 (1977); Turnbull v. Bonkowski, 419 F.2d 104, 106 (9th Cir. 1969) (federal court must respect pre-state Alaska court's interpretation of Alaska law). See generally Note, An Erie Doctrine for the District of Columbia, 62 GEO. L.J. 963, 980, 98392 (1974) (urging adoption of Erie doctrine by federal courts in District). 
proviso that, for purposes of federal district court jurisdiction, D.C. Code laws are not "laws of the United States," the Supreme Court in Key v. Doyle ${ }^{63}$ commented that this "hardly implies that Congress must have intended that references to 'laws of the United States' found in all other jurisdictional chapters and sections . . . would include provisions of the D.C. Code." federal courts apply a presumption contrary to Congress' clear intent. Unless Congress specifically states to the contrary, these courts refuse to equate the District with states, and construe the D.C. Code not as state, but as federal, law.

In District of Columbia v. Carter, ${ }^{65}$ for example, the Supreme Court held that Congress did not intend the District to be considered a "State or Territory" for purposes of 42 U.S.C. $\$ 1983$, which provides a federal forum for deprivations of constitutional rights under color of state (or territorial) law. Congress soon disavowed the Supreme Court's construction, amending the section to equate explicitly the District with the states and territories. ${ }^{68}$

In other cases, Supreme Court literalism has remained uncorrected. In Palmore v. United States, ${ }^{67}$ the Court held that D.C. Code statutes are not equivalent to state statutes for purposes of appeal as of right to the Supreme Court. ${ }^{68}$ In Key v. Doyle, ${ }^{68}$ however, the Court held that D.C. Code statutes also are not "statutes of the United States" for purposes of Supreme Court appeal. ${ }^{70}$ The result, as the Key dissent noted, is that

63. 434 U.S. 59 (1977).

64. Id. at 67 n.12; see Note, supra note 62, at 981 (imputing any significance to Congress' failure to amend U.S. Code provision to conform to new scheme "is excessively literal, considering . . . the task Congress would have faced had it decided to amend every applicable section of the judicial code in order to bring the District of Columbia courts into exact conformity with the state systems").

65. 409 U.S. 418, 432 (1973); see id. at 430 ("assumption that the Federal Government could keep its own officers under control" is equally applicable to District officers).

66. 42 U.S.C. § 1983 (Supp. V 1981); see H.R. REP. No. 548, 96th Cong., 1st Sess. 1-3 (1979), reprinted in 1979 U.S. CODE CONG. \& AD. NEWS 2609, 2609-11 (after amendment, federal courts have jurisdiction over $\S 1983$ actions against District officials acting under authority of local laws, even if those laws were passed by Congress). Carter is an anomaly, since Congress has "established an independent court system with exclusive jurisdiction over local matters." Id. at 2, 1979 U.S. CODE CONG. \& AD. NEWS at 2610. The District has the same "government structures that operate in every other locale," $i d$., and the amendment therefore "is necessary in order to give citizens of the District of Columbia rights equal to those of citizens in the states and territories of the United States." Id. at 1, 1979 U.S. CODE CONG. \& AD. NEWS at 2609.

67. 411 U.S. 389 (1973).

68. Id. at 395 ("We are entitled to assume that in amending $\S 1257$, Congress legislated with care, and that had Congress intended to equate the District Code and state statutes for the purposes of $\S 1257$, it would have said so expressly ....").

69. 434 U.S. 59 (1977).

70. The Court reasoned that mandatory appellate jurisdiction over state court judgments is reserved for cases threatening the supremacy and uniformity of federal law; no such threat exists when state courts invalidate state statutes on federal grounds, and no automatic right of appeal is provided to the Supreme Court. "From the analogy of the local D.C. courts to state courts drawn by Congress in the 1970 Act, it follows that no right of appeal should lie to this Court when a local court of the 
D.C. Code enactments are treated as "mongrel statutes," reviewable only by writ of certiorari. ${ }^{11}$ The Key decision invited Congress to legislate the necessary clarification, but Congress has not yet done so.

In addition, Congress has not extended the prohibition upon the issuance of federal injunctions staying state court proceedings ${ }^{72}$ to local District proceedings, ${ }^{73}$ nor has it eliminated the United States Attorney General's constructive custody over defendants sentenced by the local courts. ${ }^{74}$

District invalidates a law of exclusively local application." Id. at 68. The Court explained that underlying its decision in Palmore was "the long-established principle that counsels a narrow construction of jurisdictional provisions authorizing appeals as of right to this Court." Id. at 65. Although the Key majority did not expressly overrule Palmore, it did so indirectly by finding that pre-1970 methods of Supreme Court review of local law should remain applicable. Id. at 64, 66. Separate provision for Supreme Court appeal from the local court system was last provided in the Act of Mar. 3, 1911, ch. $231, \S 250,36$ Stat. 1087, 1159. Section 250(6), similar to 28 U.S.C. $\S 1257(1)$ (1976) (construed by the Court in Key), provided for appeals in "cases in which the construction of any law of the United States is drawn in question by the defendant." Just as in Key, the Court in American Sec. \& Trust Co. v. Commissioners of the Dist. of Columbia, 224 U.S. 491, 494-95 (1912), concluded that the phrase "law of the United States" in this section did not include congressional acts applicable solely to the District. Appeals could also be taken under $\S 250$ (3) of the 1911 Act, similar to $\$ 1257$ (2) (construed by the Court in Palmore) which provided for appeals in cases involving the "constitutionality of any law of the United States." Although the same words, "law of the United States," were used in both sections of the Act, the Court concluded in Heald v. District of Columbia, 254 U.S. 20, 22-23 (1920), that appeals involving the constitutionality of local statutes should be permitted under $\S$ 250(3). Heald found that $\S 250$ (3) simply reenacted statutes that had been interpreted to permit Supreme Court review in cases "concerning the constitutional power of Congress to enact local statutes" and that the prior construction to permit appeals in these cases should continue, 254 U.S. at 2223, even though this forced the Court to interpret identical words in the same jurisdictional statute in different ways. The result in Palmore cuts off one of these routes to Supreme Court review under the 1911 Act.

71. 434 U.S. at 74 (White, J., dissenting). The Key dissent noted that Key and Palmore together may remove any basis even for certiorari review of local court constructions of local statutes. Id. at 74$75 \&$ n.6. Congress should resolve this problem by providing that for purposes of $\S 1257$, D.C. Code provisions are state statutes. Cf. 28 U.S.C. $\$ 1258(2)$ (1976) (providing for Supreme Court appeal when a Puerto Rico statute is upheld against a challenge under the Constitution, just as state statutes may be appealed under 28 U.S.C. $\S 1257(2)(1976)$ ).

72. 28 U.S.C. $\S 2283$ (1976).

73. See Shapiro v. Thompson, 394 U.S. 618, 625 n.4 (1969); Police Officers' Guild v. Washington, 369 F. Supp. 543, 549 (D.D.C. 1973).

74. D.C. CODE ANN. § 24-425 (1981). When the U.S. Attorney General takes custody of persons and designates their place of confinement pursuant to a Superior Court order he should be considered as acting in a nonfederal capacity. McCall v. Swain, 510 F.2d 167, 180 n.34 (D.C. Cir. 1975); see Borders v. Reagan, 518 F. Supp. 250, 258 (D.D.C. 1981) (dictum) (federal employee not an "officer of the United States" when execution of his duties does not involve interpreting and enforcing federal law). The U.S. Code does not give the Attorney General jurisdiction over local prisoners in his custody: 18 U.S.C. $\S 4082$ (a) (1976) gives him custody only of "person[s] convicted of an offense against the United States," a category that should not include D.C. Code offenders. See Milhouse v. Levi, 548 F.2d 357, 362 n.13 (D.C. Cir. 1976). The D.C. Department of Corrections has actual custody of local inmates and under D.C. CODE ANN. \$ 24-442 (1981 \& Supp. 1982) must provide "proper treatment, care, rehabilitation and reformation" for those inmates when they are incarcerated in the District's prison facilities.

The D.C. Circuit has interpreted these provisions inconsistently. In Cannon v. United States, 645 F.2d 1128 (D.C. Cir. 1981), the court held that since the District's Mayor and Council have charge of Lorton prison, id. at 1136-37, the legal fiction of "custody of the Attorney General" does not suffice as a basis for a Lorton inmate suit against prison officials under the Federal Tort Claims Act, id. at 1141-42. In Milhouse v. Levi, 548 F.2d 357, 363 (D.C. Cir. 1976), however, the court held that Congress' failure to amend the provision under which the Attorney General nominally regulates Lor- 
Congress also has failed to exclude the local courts from the category of "courts established by Act of Congress" that may issue writs under the All Writs Act, ${ }^{75}$ and despite the existence of a separate writ statute in the D.C. Code, ${ }^{76}$ the D.C. Circuit has ruled that the local courts may issue writs under either the U.S. or the D.C. Code provision. ${ }^{77}$

The most problematic anomaly still remaining is the continued prosecution of defendants in the local courts by the United States Attorney for the District of Columbia. Attempts to create a local prosecutor's office have failed. ${ }^{78}$ Because local cases are prosecuted by the United States Attorney, they continue to be brought in the name of the United States. This proce-

ton furlough programs was significant evidence that Congress intended federal control to continue. See Dobbs v. Neverson, 393 A.2d 147, 149 \& n.6 (D.C. 1978) (Attorney General custody justifies application of federal, rather than District, good time rule to offenders sentenced by local court and transferred from Lorton to mental hospital); Rivers v. United States, 334 A.2d 179, 182 (D.C. 1975) (because of Attorney General's custody, Lorton inmates may be tried in federal court under federal escape statute); see also United States v. Perez, 488 F.2d 1057, 1059 (4th Cir. 1974) (federal court jurisdiction upheld over prisoner assault on guard at Lorton).

Lorton should explicitly be recognized as a local facility. Though established by an Act of Congress, Act of Mar. 3, 1909, ch. 250, 35 Stat. 688, 717, Lorton is "an integral part of the District of Columbia correctional system." McCall v. Swain, 510 F.2d 167, 170 (D.C. Cir. 1975). The D.C government exercises actual powers of government over the area. D.C. CODE ANN. § 24-442 (1981 \& Supp. 1982); see Board of Supervisors v. United States, 408 F. Supp. 556, 564 n.10 (E.D. Va. 1976) (U.S. is merely legal titleholder of Lorton land; actual powers of government over area are exercised by the District, and Lorton is governed by District law), dismissed mem. sub nom. Board of Supervisors v. District of Columbia, 551 F.2d 305 (4th Cir. 1977); see also 119 CONG. REC. 22,955 (1973) (statement of Sen. Eagleton) (District government should maintain own penal institutions as exercise of self-government); see also D.C. CODE $\Lambda N N$. $\$ 24-422$ (1981) (District must bear cost of maintaining D.C. Jail facility); id. $\$ 24-423$ (District must reimburse U.S. for federal funds expended on maintenance of District inmates).

75. 28 U.S.C. $\S 1651$ (1976).

76. D.C. CODE ANN. § 16-1901 (1981).

77. United States v. Cogdell, 585 F.2d 1130, 1133-34 (D.C. Cir. 1978) (superior court may issue writ under 28 U.S.C. $\S 1651$, and when it does so, writ is "issued under the laws of the United States"), rev'd on other grounds sub nom. United States v. Bailey, 444 U.S. 394 (1980). Other anomalies are found in the D.C. Rules of Criminal Procedure: e.g., rule 5-1 (if arrest outside the District pursuant to superior cour: warrant, defendant may be removed to the District under the Federal Rules of Criminal Procedure rather than through extradition proceeding); rule 6 (grand jury summoned by superior court may return indictments in superior or district court); rule 9 (superior court warrant for D.C. Code offense may be delivered either to U.S. Marshal or to D.C. Chief of Police), see United States v. Boettcher, 588 F.2d 89, 90 (4th Gir. 1978) (because delivered to U.S. Marshal, superior court arrest warrant for D.C. Code offense was issued under "law of the United States"); rule 20 (D.C. Code violators outside the District may waive local trial and consent to disposition in U.S. district court where located), see United States v. Ford, 627 F.2d 807, 812 n.5 (7th Cir.) (upholding application of rule 20 to D.C. Code violators who plead guilty in federal district court outside the District), cert. denied, 449 U.S. 923 (1980); rule 40 (superior court may release or detain U.S. Code offenders in certain circumstances), see D.C. CODE ANN. \$ 11-923(c)(2) (1981).

78. The District's delegate to Congress introduced a bill in the House in 1981 to establish a local Attorney General's office, and to transfer prosecutorial authority for local offenses and custodial responsibility for local prisoners to the D.C. government, H.R. 1253, 97th Cong., 1st Sess. (1981), but the bill failed to reach the House floor. A local prosecutor would be consistent with the scheme adopted in other jurisdictions. See 48 U.S.C. $\S 1694$ (c) (Supp. V 1981) (providing for both U.S.

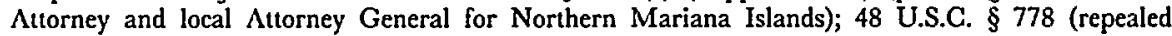
1950) (providing local Attorney General for Puerto Rico); see also Snow v. United States, 85 U.S. (18 Wall.) 317,321 (1873) (upholding power of elected local prosecutor to prosecute offenses against territorial laws). 


\section{D.C. Jurisdiction}

dure in turn is used to justify the retention of Article III jurisdiction over D.C. Code offenses and to support the characterization of D.C. Code violations as offenses against the United States. ${ }^{79}$

\section{D. "Federal" Offenses and Non-Article III Courts}

The logic by which D.C. Code offenses are considered crimes against the United States is consistent neither with the jurisdiction conferred by Congress upon the District's two court systems, nor with the constitutional power of Congress to vest certain matters in non-Article III courts.

Under the Judiciary Act, the district courts of the United States have exclusive jurisdiction over prosecutions for crimes against the United States. ${ }^{80}$ Congress has not amended that provision to carve out an exception for prosecutions under the D.G. Code. It has merely vested jurisdiction over all laws applicable only to the District of Columbia in a nonArticle III court system of general jurisdiction. This division of jurisdiction suggests that Congress does not intend to equate D.C. Code and U.S. Code offenses.

Had Congress instead defined D.C. Code violations as "offenses against the United States" but excepted them from the exclusive jurisdiction of Article III courts, that exception could not withstand scrutiny. Since jurisdiction over offenses against the United States is part of the "protected core" of Article III power, ${ }^{81}$ Congress cannot divest Article III courts of this jurisdiction and place it,instead in non-Article III courts. ${ }^{82}$ The Court

79. Dobbs v. Neverson, 393 A.2d 147, 149 (D.C. 1978); see United States v. Kember, 648 F.2d 1354, 1358-59 (D.C. Cir. 1980) (U.S. Attorney's power to prosecute D.C. Code offenses supports federal jurisdiction over local offenses despite dismissal of federal charges); United States v. Ford, 627 F.2d 807, 812 (7th Cir.) (U.S. Attorney's prosecution of local offenses in name of United States justifies retention of jurisdiction over District offenses by federal district courts outside the District), cert. denied, 449 U.S. 923 (1980); United States v. Jackson, 562 F.2d 789, 806 (D.C. Cir. 1977) (MacKinnon, J., dissenting in part) (U.S. Attorney's prosecution of both federal and local offenses supports their joinder in single trial in federal court); Hackney v. United States, 389 A.2d 1336, 1339 (D.C. 1978) (U.S. Attorney's power to prosecute D.C. Code offenses justifies return of indictments by grand jury called by local court in either local or federal court).

80. 18 U.S.C. $\S 3231$ (1976).

81. Northern Pipeline Constr. Co. v. Marathon Pipe Line Co., 102 S. Ct. 2858, 2871 n.25 (1982).

82. The power of Congress to create non-Article III courts and the type of jurisdiction with which they can be invested has been much disputed. It may be argued that the Framers never intended to create any source of federal judicial power other than Article III. THE FEDERALIST Nos. 80, 81, 82 (A. Hamilton); 2 RECORDS OF THE FEDERAL CONVENTION 45-46, 423-25 (M. Farrand rev. ed. 1937); P. BATOR, P. MISHKIN, D. ShaPIRo \& H. WEChSlER, HART \& WEChSLER'S THE Federal CouRTS AND THE FEDERAL SYSTEM 7-25 (2d ed. 1973). Attempting to ensure the separation of governmental powers, the Framers sought an unbiased and independent judiciary that would exercise only judicial power. THE FEDERALIST Nos. 78, 79 (A. Hamilton); 1 RECORDS OF THE FEDERAL CONVENTION, supra, at 97-98, 108-10; 2 id. at 428-29; see O'Donoghue v. United States, 289 U.S. 516, 530-31 (1933).

Article I, § 8, cl. 9, conferring power upon Congress "to constitute Tribunals inferior to the supreme Court," thus may refer only to those courts that Article III permits Congress to constitute. 
Reform Act's removal of D.G. Code criminal proceedings from Article III court jurisdiction can be justified only if those proceedings are not federal in nature.

The Supreme Gourt confronted this issue in Palmore v. United States. ${ }^{83}$ In that case, the Court justified non-Article III court jurisdiction over D.C. Code offenses by analogy to state court enforcement of federal penal laws. ${ }^{84}$ Congress, however, never has required state courts to enforce fed-

Katz, supra note 14, at 894 n.2; Note, The Distinction Between Legislative and Constitutional Courts and Its Effect on Judicial Assignment, 62 CoLUM. L. REV. 132, 137 n.28, 149-50 (1962). Although the "necessary and proper" clause, Article I, $\S 8, \mathrm{cl} .18$, grants broad implied powers to Congress, it should not be interpreted to grant an additional court-creating power, since that power is enumerated in another section of the Constitution. Congress' implied power over section 8 subjects does allow it to create administrative bodies exercising quasi-judicial power; for this reason the Court held in $E x$ parte Bakelite Corp., 279 U.S. 438, 451 (1929), that Article I courts may be created to determine matters "arising between the government and others, which from their nature do not require judicial determination and yet are susceptible of it." Non-Article III trial courts may be constituted to determine these "public rights" cases, and the principle of separation of powers is satisfied by review of these matters in an Article III court. See Northern Pipeline Constr. Co. v. Marathon Pipe Line Co., 102 S. Ct. 2858, 2894 (1982) (White, J., dissenting).

Congress' power to create local District courts, however, derives from its general sovereign powers over the District, a wholly different source than that of its power to create courts to adjudicate "public rights." The Supreme Court's recent opinion in Northern Pipeline, 102 S. Ct. at 2868-71, does not serve the cause of clarity by describing the two types of courts under a single rubric, as "Iegislative courts." As the four-member dissent in that case notes, there are fatal flaws in this unitary theory, and in characterizing Congress' power to create all non-Article III courts in the District simply as "geographical." Id. at 2888-89 \& n.8 (White, J., dissenting); see also In re Cox Cotton Co., 24 B.R. 930, 952-54 (E.D. Ark. 1982) (distinguishing District of Columbia courts, which exercise judicial power, from other courts with narrow subject matter jurisdiction established under Article I, which do not exercise judicial power).

Although the United States is a party to criminal proceedings, those proceedings do not adjudicate "public rights." Northern Pipeline, 102 S. Ct. at 2871 n.24. Federal criminal proceedings remain at the "protected core" of Article III judicial power, id. at 2871 n.25, and must remain subject to Article III adjudication. See infra notes $85-88$. If Congress' section 8 powers, including the power to define local criminal offenses under clause 17, are deemed to be coequal, and District offenses therefore are defined as "federal," the separation of powers principle must apply to the local courts created by Congress to try those offenses. (That Congress may vest some of the federal judicial power in state courts has no relevance to the integrity of this principle and its application to congressionally created non-Article III courts. Northern Pipeline, 102 S. Ct. at 2867 n.15.). The principle would require that those courts be invested with Article III tenure and salary guarantees, especially since the U.S. government prosecution of D.C. Code violations may undermine the impartiality of judges without those protections. See Brown, The Rent in Our Judicial Armor, 10 GEo. WASH. L. REV. 127, 129 (1941) (Article III protections doubly needed in cases in which U.S. government is party). These difficulties may be avoided, first, by defining D.C. Code offenses as "crimes against the District of Columbia," and second, by defining the District's local courts not as "federal courts with limited geographical reach" but instead as quasi-state courts, constituted under Congress' state-like power in the District, with jurisdiction over local law matters, including criminal offenses. These courts do exercise judicial power, not of the United States, but of the District of Columbia, and have nothing in common with quasi-administrative public rights adjudicatory bodies. This different theoretical framework for the two types of courts serves to explain the current status of the District's courts in a more satisfactory and consistent way.

83. 411 U.S. 389 (1973).

84. Id. at 402,407 . The Court in Palmore also analogized the jurisdiction of the District's local courts to that exercised by territorial courts, id. at 403 , but the Court disregarded an important distinction between territorial courts and courts of the District. The federal question jurisdiction of territorial courts without Article III protections has been justified by the ephemeral nature of the territories and the temporary nature of their courts. McAllister v. United States, 141 U.S. 174, 187-88 
eral criminal laws. ${ }^{85}$ On the contrary, the Judiciary Act of 1789 vested exclusive jurisdiction over offenses against the United States in the United States courts, ${ }^{86}$ and Congress never has divested Article III courts of this exclusive jurisdiction. ${ }^{87}$ In addition, Supreme Court precedent that the states may not be required to enforce federal criminal law never has been overruled. ${ }^{88}$ Thus, the analysis in Palmore is exactly backward: It is not Congress' clause 17 power to create state-like courts that allows it to vest "federal" causes of action in the District in non-Article III tribunals, but Congress' clause 17 ability to create state-like claims that justifies the use of non-Article III courts to hear those claims. ${ }^{89}$

(1891). The District, however, is a permanent entity. Residents of the District, unlike those of the territories, were entitled to an Article III forum when prosecuted for federal crimes prior to the cession of the District to the United States, and that right was not taken away by cession. O'Donoghue v. United States, 289 U.S. 516, 540 (1933). In 1801, Congress created the first court system for the District, and vested criminal jurisdiction in a tenured circuit court. See infra note 89 . In 1933, the Court in O'Donoghue held that although Congress had not originally classified these courts as Article III courts, they exercised federal judicial power in part and must be considered as established under Article III. The Palmore analogy of the District's courts to territorial courts in order to justify non-Article III jurisdiction over what it described as "federal" offenses therefore is inappropriate.

85. The Court in Palmore cited Warren, Federal Criminal Laws and the State Courts, 38 HaRV. L. REV. 545, 551-53, 570-72 (1925), see 411 U.S. at 402, for the proposition that "[v]ery early in our history, Congress left the enforcement of selected federal criminal laws to State courts." Warren, however, does not support this conclusion. Warren cites only one instance in which criminal jurisdiction was conveyed by Congress to state courts, in the Act of Mar. 2, 1799, ch. 42, § 28, 1 Stat. 733, 740-41. See Warren, supra, at 554 \& n.25. This statute, which created a United States Post Office, defined certain state-like offenses connected with mail delivery and provided that state courts would be permitted to exercise jurisdiction over those offenses when similar offenses were defined by the state as state law violations. By contrast, Congress never authorized state courts to try crimes that are typically federal. See Stearns v. United States, 22 F. Cas. 1188, 1192 (C.C. 1835) (No. 13,341) (state courts "cannot hold criminal jurisdiction over offences exclusively existing, as offences against the United States"). All other examples cited by Warren involve penal actions for fines and forfeitures, not criminal violations. See Stearns at 1192 ("Actions for penalties are civil actions, both in form and in substance." Statc court "jurisdiction of federal causes. . . is confined to civil actions for civil demands or to enforce penal statutes").

86. Act of Sept. 24, 1789, ch. 20, §11, 1 Stat. 72, $78-79$ (circuit courts of the United States "shall have exclusive cognizance of all crimes and offences cognizable under the authority of the United States, except where . . . the laws of the United States shall otherwise direct, and concurrent jurisdiction with the district courts of the crimes and offences cognizable therein"); id. $\$ 9,1$ Stat. 76-77 (district courts given jurisdiction over federal misdemeanors exclusively of state courts).

87. 18 U.S.C. $\S 3231$ (1976).

88. See Houston v. Moore, 18 U.S. (5 Wheat.) 1, 69 (1820) (U.S. criminal jurisdiction may not be delegated to state tribunals); Martin v. Hunter's Lessee, 14 U.S. (1 Wheat.) 304, 337 (1816) (same). But see F. FRANKFURTER \& J. LANDIS, THE BUSINESS OF THE SUPREME COURT 293 (1928) (advocating state court enforcement of state-like federal offenses); Frankfurter, Distribution of Judicial Power Between United States and State Courts, 13 CORNELL L.Q. 499, 516 \& n.94 (1928) (jurisdiction of minor federal offenses should be vested in state courts); cf. Testa v. Katt, 330 U.S. 386,394 (1947) (Congress may require state courts to enforce federal penal laws in civil actions for penalties); 60 HARV. L. REV. 966, 972 (1947) (Testa may open way for Congress to require state courts to try federal offenses).

89. In fact, courts without Article III protections have been vested with jurisdiction over some local offenses throughout the District's history. In 1801, Congress created a tenured circuit court, Act of Feb. 27, 1801, ch. 15, $\S 3,2$ Stat. 103, 105, giving it jurisdiction "of all crimes and offences committed within" the District, id. $\S 5,2$ Stat. 106, but simultaneously provided for the continuation of local criminal powers vested by state laws previously in force in nontenured justices of the peace 
If D.C. Code violations are not "offenses against the United States," the United States Attorney acts in a nonfederal capacity when he prosecutes claims arising under the D.C. Code. ${ }^{90}$ In that capacity he is not an officer of the United States but represents instead the real party in interest in local District prosecutions, the people of the District of Columbia and their local government. ${ }^{91}$ Accordingly, the presence of the United States in local prosecutions cannot serve as an independent basis for Article III jurisdiction over local offenses.

\section{E. Needed Changes}

The current confusion over the nature of the D.C. Gode can be cleared away by simple definitional changes. In addition to identifying the real party in interest in District of Columbia local prosecutions as the local District government, violations of the D.C. Code must be defined as crimes against the District of Columbia, equivalent to state offenses, not as crimes against the United States. ${ }^{92}$ These changes would promote the

(who sat together as local legislative levy courts with power to define local criminal offenses). Id. $\S 11$, 2 Stat. 107; see Franchino, supra note 17 , at $215 \&$ n.23. In 1838 , Congress created a nontenured criminal court, giving it jurisdiction "of all crimes and offences against the laws now in force in" the District, exercising this jurisdiction concurrently with the justices of the peace. Act of July 7, 1838, ch. $192, \S 1,5$ Stat. 306 . In 1863 , this criminal court vas made a special term of the tenured supreme court. Act of Mar. 3, 1863, ch. 91, $\S 3,12$ Stat. 762, 763. In 1870, Congress divested the supreme court and the justices of the peace of their jurisdiction over all noninfamous offenses committed within the District, vesting exclusive jurisdiction over those offenses "and of all offences against any of the ordinances of the city of Washington, or of the city of Georgetown, or laws of the levy court of the county of Washington" in a nontenured police court. Act of Jun. 17, 1870, ch. 133, § 1, 16 Stat. 153. Congress provided that the cities of Washington and Georgetown, and the levy court of Washington county, would bear the costs of the new court through assessments upon District residents. In addition, Congress specified that offenses defined by the cities and by the levy courts would be prosecuted not by the U.S. Attorney but by city or levy court attorneys. Id. $\S 16,16$ Stat. 156. Although Congress has changed the form of the District's courts several times since 1870 , it is clear from the foregoing history that Congress has never considered offenses defined by local District authorities to be offenses against the United States.

90. See supra note 16.

91. Id. Because the D.C. government may not change the duties of the District's U.S. Attorney, D.C. CODE ANN. $\$ 1-233(\mathrm{a})(8)$ (1981), Congress must make this definitional change.

92. See supra note 15 . An additional reason to change the present nomenclature is that local District prisoners, considered to have committed "crimes against the United States," are classified for purposes of incarceration as "federal" prisoners. Under D.C. CODE ANN. § 24-425 (1981), the U.S. Attorney General may designate D.C. Code violators not only to Lorton, where they are considered for parole under District parole standards, see D.C. CODE ANN. § 24-204 (1981), but also to any federal prison, where they receive federal parole consideration due to the U.S. Parole Commission's interpretation of D.C. CODE ANN. $§ 24-209$ (1981) (federal parole board given "same power and authority" to parole prisoners convicted in the District of "crimes against the United States" as is vested in the District's parole authority). The Commission interprets $\$ 24-209$ as a grant of authority to determine parole of D.C. Code offenders housed in federal facilities under the federal parole statute and regulations. See Cosgrove v. Smith, 697 F.2d 1125, 1129 (D.C. Cir. 1983). The author of this Note has represented inmates who challenged this interpretation on two grounds: first, that $\S 24-209$ requires that the U.S. Parole Commission apply the District's parole criteria, and second, that the use of two different parole statutes and regulations in determining the parole of similar D.C. Code offenders violates equal protection. Id. Compare 18 U.S.C. $\$ 4206$ (1976) (federal parole statute) and 28 
uniform treatment of District residents by the various sources of authority in the District and would best comport with Congress' intent in restructuring the local and federal governmental and judicial frameworks in the District into separate and autonomous units. Defining the D.G. Code as nonfederal removes actions arising under that Code from the category of cases that may fall within the "arising under" jurisdiction of Article III courts. The Code instead would be interpreted and enforced uniformly by an independent court system. Under this framework, section 11-502(3) may not be interpreted as a mere allocation of "federal" jurisdiction among the courts of the District, ${ }^{93}$ but instead as a statutory embodiment of the pendent jurisdiction concept applied to criminal cases. ${ }^{94}$

\section{Examining "Criminal Pendent Jurisdiction"}

The standards for the exercise of pendent jurisdiction have been delineated by the Supreme Court in United Mine Workers v. Gibbs, ${ }^{95}$ and are applicable to pendent local District claims for the same reasons that they govern pendent state law claims. ${ }^{96}$ Under Gibbs, the federal court has "power" to hear local causes of action normally outside its limited jurisdiction when the federal and local claims derive from a "common nucleus of operative fact." nal pendent actions under section 11-502(3); it is satisfied if the federal and local charges arise out of the "same transaction" for trial under Federal Rule of Criminal Procedure 8(a)..$^{98}$ Gibbs also

C.F.R. $\S \S 2.12-2.20$ (1982) (federal parole regulations) with D.C. CoDE ANN. § 24-204 (1981) (District parole statute) and District of Columbia Parole Board, Guidelines for Initial Adult Parole Hearing (1982) (District parole regulations) (on file with Yale Law Journal).

93. See supra note 14.

94. See supra note 10 .

95. 383 U.S. 715 (1966).

96. Financial Gen. Bankshares, Inc. v. Metzger, 680 F.2d 768, 772-74 (D.C. Cir. 1982); Thomas v. Barry, 543 F. Supp. 801, 804 \& n.3 (D.D.C. 1982); Wachovia Bank \& Trust Co. v. National Student Mktg. Corp., 461 F. Supp. 999, 1010 (D.D.C. 1978), rev'd on other grounds, 650 F.2d 342 (D.C. Cir. 1980), cert. denied, 452 U.S. 954 (1981); National Tire Wholesale, Inc. v. Washington Post Co., 441 F. Supp. 81, 88-89 (D.D.C. 1977), aff'd mem., 595 F.2d 888 (D.C. Cir. 1979); Houlihan v. Anderson-Stokes, Inc., 434 F. Supp. 1324, 1329-30 (D.D.C. 1977); Marshall v. District of Columbia, 392 F. Supp. 1012, 1018 (D.D.C. 1975), rev'd on other grounds, 559 F.2d 726 (D.C. Cir. 1977).

97. Gibbs, 383 U.S. at 725.

98. United States v. Jackson, 562 F.2d 789, 797 (D.C. Cir. 1977) (rule 8 "same transaction" test gives court power over D.C. Code offenses, and "resolution of the joinder issue has jurisdictional significance"); see also Note, UMW v. Gibbs and Pendent Jurisdiction, 81 HARV. L. REV. 657, 661 (1968) (Gibbs test very similar to Federal Rule of Civil Procedure 13(a) "same transaction" test for compulsory counterclaims). But see United States v. Kember, 648 F.2d 1354, 1360 (D.C. Cir. 1980) (resolution of the joinder issue is solely "a matter of sound exercise of the court's discretion, not a question of its power"); United States v. Shepard, 515 F.2d 1324, 1330 (D.C. Cir. 1975) (urging broader criminal pendent jurisdiction).

99.

Two or more offenses may be charged in the same indictment or information in a separate 
vests certain supervisory responsibilities in the trial court, and identifies situations in which pendent civil claims should be dismissed without prejudice. Due to the different characteristics of criminal trials, however, the trial court in criminal pendent jurisdiction cases cannot fulfill its Gibbs responsibilities.

\section{A. The Gibbs Requirements in the Civil Context}

Under Gibbs, the federal court has no subject matter jurisdiction over any case in which the federal claims are insubstantial. ${ }^{100}$ Even when the court has jurisdictional power, it should exercise its discretion to refuse to adjudicate certain local claims. For example, when all federal claims are dismissed before trial, the local District claims should be dismissed as well. ${ }^{101}$ The action should also be dismissed when a District claim raises a novel and unsettled issue of law; ${ }_{;}^{102}$ the federal court should allow local courts the opportunity to first decide the issue, ${ }^{103}$ since the District of Columbia, like the states, is entitled to an internally consistent elaboration of its law by its own courts. ${ }^{104}$ The coherence of local law is disrupted by

count for each offense if the offenses charged . . . are of the same or similar character or are based on the same act or transaction or on two or more acts or transactions connected together or constituting parts of a common scheme or plan.

FED. R. CRIM. P. 8(a); see also D.C. CODE ANN. § 23-311(b) (1981) (parallel D.C. Code provision).

100. United Mine Workers v. Gibbs, 383 U.S. 715, 725 (1966); Financial Gen. Bankshares, Inc. v. Metzger, 680 F.2d 768, 772 (D.C. Cir. 1982); Thomas v. Barry, 543 F. Supp. 801,804 n.3 (D.D.C. 1982); Note, supra note 98, at 666. But see Rosado v. Wyman, 397 U.S. 397, 404 (1970) ("the view that an insubstantial federal question does not confer jurisdiction . . . [is] more ancient than analytically sound").

101. United Mine Workers v. Gibbs, 383 U.S. 715, 726 (1966); Financial Gen. Bankshares, Inc. v. Metzger, 680 F.2d 768, 773 (D.C. Cir. 1982).

102. Moor v. County of Alameda, 411 U.S. 693, 716 (1973); Financial Gen. Bankshares, Inc. v. Metzger, 680 F.2d 768, 772, 775-76 (D.C. Cir. 1982); Houlihan v. Anderson-Stokes, Inc., 434 F. Supp. 1324, 1330 (D.D.C. 1977); Wechsler, Federal Jurisdiction and the Revision of the Judicial Code, 13 LAW \& CONTEMP. PROBS. 216, 233 (1948); Note, supra note 98, at 666.

103. Financial Gen. Bankshares, Inc. v. Metzger, 680 F.2d 768, 772-73, 778 (D.C. Cir. 1982) (comity interest leads to dismissal); National Tire Wholesale, Inc. v. Washington Post Co., 441 F. Supp. 81, 88-89 (D.D.C. 1977) (dismissal of pendent District claim promotes "policy of avoiding needless resolution of state claims in federal courts"), aff'd mem., 595 F.2d 888 (D.C. Cir. 1979); Houlihan v. Anderson-Stokes, Inc., 434 F. Supp. 1324, 1329-30 (D.D.C. 1977) (once federal claims are dismissed on defendant's motion for summary judgment, comity and justice require that the court dismiss the District local law claims, citing Gibbs); Trivits v. Wilmington Inst., 417 F. Supp. 160, 169 (D. Del. 1976) (where federal claim dismissed after trial, state claim in interest of comity should be interpreted by state courts). But see Rosado v. Wyman, 397 U.S. 397, 405 (1970) (refusing to adopt "conceptual approach that would require jurisdiction over the primary claim at all stages as prerequisite to resolution of the pendent claim").

104. Lee v. Flintkote Co., 593 F.2d 1275, 1278 n.14 (D.C. Cir. 1979) ("[W]ere we not to yield a measure of deference to the District of Columbia Court of Appeals, two courts-neither of which could review the other's decisions-would engage independently in the process of formulating the local law of the District. That would subvert the dual aims of . . . discouraging forum shopping and promoting uniformity within any given jurisdiction on matters of local substantive law."); Bethea v. United States, 365 A.2d 64, 71 (D.C. 1976) ("In our system of jurisprudence, which so greatly values the doctrine of stare decisis, the ability to shape and control the precedential foundations of the law is essential to the independence of a particular judicial structure." The D.C. Court of Appeals has an 
federal court interpretations, since local courts may be reluctant to create a conflict with a federal construction, and therefore may be constrained in their later consideration of the same issues. ${ }^{105}$ The chilling effect is especially disturbing in the District, where courts of general jurisdiction, created a mere thirteen years ago, have not yet had an opportunity to develop a substantial body of law. ${ }^{108}$ The federal court also should exercise its discretion to dismiss pendent claims if the joinder of federal and local claims may confuse the jury. ${ }^{107}$

\section{B. Applying Gibbs in the Criminal Context}

The federal court can fulfill its Gibbs responsibilities only if it is able to refuse jurisdiction, since the distinctive characteristic of the Gibbs test is the supervisory responsibility it places upon the federal trial court ${ }^{108}$ to preserve comity between federal and local courts, to prevent "forum-shopping" by dismissing cases with insubstantial federal claims, and to promote fairness by dismissing claims likely to confuse a jury. But in the criminal context, the court's discretion to refuse to adjudicate a pendent claim is restricted, if not entirely eliminated. In criminal prosecutions, unlike civil suits, jeopardy attaches ${ }^{109}$ to all charges as soon as a jury is empaneled $^{110}$ or the judge begins to hear evidence. ${ }^{111}$ Following that attachment, charges dismissed in the federal court cannot be brought in the local court; ${ }^{112}$ there is no possibility of "dismissal without prejudice."

Perhaps due to this consequence of dismissing pendent local criminal charges, the District's federal courts have been reluctant to order dismissal, even in cases in which they should have no jurisdictional power to

\footnotetext{
"obligation to fulfill the mandate of the Court Reorganization Act by preserving the autonomous authority of our judicial structure."), cert. denied, 433 U.S. 911 (1977); 74 HARV. L. REV. 1660, 1662 (1961) (state normally entitled to elaboration of its law by its own courts).

105. Wechsler, supra note 102, at 232 (federal courts are not authorized state law expositors; no mechanism by which state courts can correct federal court errors), cited with approval in United Mine Workers v. Gibbs, 383 U.S. 715, 726 n.15 (1966); Note, supra note 98, at 666 (state consideration limited following federal court's holding on novel issue of state law; because of possible reliance, state court hesitant to create conflict with federal determination).

106. See Financial Gen. Bankshares, Inc. v. Metzger, 680 F.2d 768, 771 (D.C. Cir. 1982) (district court improperly retained jurisdiction over local claim because District's local courts had not yet had opportunity to define applicable standards).

107. United Mine Workers v. Gibbs, 383 U.S. 715, 726 (1966); Houlihan v. Anderson-Stokes, Inc., 434 F. Supp. 1324, 1330 (D.D.C 1977).

108. Note, supra note 98 , at 666 .

109. U.S. CONST. amend. V ("No person shall be . . . subject for the same offence to be twice put in jeopardy of life or limb....").

110. Serfass v. United States, 420 U.S. 377,388 (1975).

111. Lee v. United States, 432 U.S. 23, 27 n.3 (1977); Serfass v. United States, 420 U.S. 377, 388 (1975).

112. A defendant can be brought to trial again only in very limited circumstances. See Westen \& Drubel, Toward a General Theory of Double Jeopardy, 1978 SUP. CT. REV. 81.
} 
hear the local claims. ${ }^{113}$ This practice promotes jury prejudice, and allows prosecutors to "forum shop" for federal evidentiary rules that may have a material effect on the outcome of the litigation, even though the federal count used to gain access to that forum is insubstantial and ultimately is dropped. ${ }^{114}$ Further, these restrictions on the federal court's supervisory power hamper its ability to prevent the harsher treatment produced by the joinder statute for defendants convicted of U.S. Code offenses within the District compared to U.S. Code violators in the fifty states.

\section{Multiplicity and Jury Prejudice}

Courts and commentators have noted that the practice of charging multiple counts under a single code for one criminal act increases the possibility of jury prejudice and hostility, and the danger of a compromise verdict. ${ }^{115}$ Multiplicitous indictments are tolerated, and defendants may not move to strike counts on grounds of multiplicity, because courts presume that Congress legislates with care and intends that the offenses it defines in separate sections of the U.S. Code (or of the D.C. Code) will be separately charged. ${ }^{116}$ The presumption that Congress does not intend dupli-

113. Disposition of the federal charge prior to trial, or severance of the federal and local charges, should dictate dismissal of the local charges for lack of jurisdictional power. See United States v. Jackson, 562 F.2d 789, 797, 800 (D.C. Cir. 1977) (district court loses jurisdiction when local charge severed prior to trial; court must dismiss local action and U.S. Attorney must reindict in Superior Court). The D.C. Circuit has also held, however, that "[o]nce the federal court has acquired jurisdiction, it may determine all questions arising, irrespective of the disposition of the federal claim." United States v. Shepard, 515 F.2d 1324, 1330 (D.C. Cir. 1975) (district court may retain jurisdiction to conclude trial of D.C. Code offenses even though Government dismissed federal charges prior to submission of case to jury); see United States v. Kember, 648 F.2d 1354, 1359 (D.C. Cir. 1980) ( $\$$ 11-502(3) "does not suggest that any disposition of the federal offense, subsequent to proper joinder in an indictment, withdraws power over the local offense"); id. at $1359 \mathrm{n} .9$ (although court agrees with holding in Jackson, it would not have based dismissal on jurisdictional grounds, but instead on trial court's discretionary powers).

114. See United States v. Jackson, 562 F.2d 789, 793 (D.C. Cir. 1977) ("Ip]lainly" it would be "an unacceptable situation" in light of Congress" determination that District offenses should generally be tried in the District's courts to so strain rule 8 joinder by the "simple expedient of adding at least one federal count to any indictment").

115. Crisafi v. United States, 383 A.2d 1, 3 n.2 (D.C.), cert. denied, 439 U.S. 931 (1978); Bridges v. United States, 381 A.2d 1073, 1075 (D.C. 1977), cert. denied, 439 U.S. 842 (1978); see United States v. Alston, 609 F.2d 531, 534 (D.C. Cir. 1979) (because of $\$ 11-502$ (3) joinder, "[p]yramiding charges is particularly troublesome in" the District), cert. denied, 445 U.S. 918 (1980); United States v. Ketchum, 320 F.2d 3, 8 (2d Cir.) (risk of prolix pleading's having psychological effect upon jury), cert. denied, 375 U.S. 905 (1963); Note, Double Jeopardy and the Multiple-Count Indictment, 57 YALE L.J. 132, 133 (1947) (multiple count indictments "greatly enhance the potential penalty for any given criminal transaction").

116. The U.S. Attorney may charge the same offense several times in an indictment in different counts. Although the defendant may move before trial under Federal Rule of Criminal Procedure 12 to dismiss the indictment as multiplicitous, the defendant cannot move to strike counts on the ground of multiplicity, $8 \mathrm{~J}$. MOORE, MOORE'S FEDERAL PRACTICE If 8.07[1], and the jury can convict on the multiplicitous counts, subject only to the limitation that consecutive sentences may not be imposed, North Carolina v. Pearce, 395 U.S. 711, 717-18 (1969) (double jeopardy prohibition on multiple punishment for same offense); see Iannelli v. United States, 420 U.S. 770,786 n.18 (1975) (greater 
cation does not hold once two separate codes are available to the prosecutor for charging. ${ }^{117}$ The two codes often are aimed at deterring and punishing the same criminal conduct, and aside from federal jurisdictional elements, they describe the "same offenses" in many parallel provisions. ${ }^{118}$ Recognizing this, the District's federal courts refuse to permit double convictions for similar U.S. and D.C. Code charges. ${ }^{119}$

By increasing the number of available charging provisions, section 11502(3) joinder expands the prosecutor's already broad discretion to include multiple charges in a single indictment, and creates a corresponding increase in jury prejudice. The effects of the availability of two self-contained codes for charging must nullify the presumption that multiplicity is tolerable. ${ }^{120}$ The absence of any checks on the prosecutor's section 11-

and lesser offenses may not be separately punished).

117. The D.C. Circuit has held, however, that "it is for the U.S. Attorney to determine whether to prosecute under both [federal and local] statutes or only one." United States v. Shepard, 515 F.2d 1324, 1336 (D.C. Cir. 1975).

118. The test used to determine whether two statutory provisions describe two offenses or only one is "whether each provision requires proof of a fact which the other does not." Blockburger v. United States, 284 U.S. 299, 304 (1932). Only the "essential elements" of two offenses need be the same under Blockburger, United States v. Sampol, 636 F.2d 621, 653-54 (D.C. Cir. 1980), and the only difference between many D.C. and U.S. Code offenses is the element of federal jurisdiction-not an "essential element" for Blockburger purposes. United States v. Blassingame, 427 F.2d 329, 330 (2d Cir. 1970) (federal jurisdiction element "is logically no part of the crime itself" and therefore prosecution need not prove defendant's knowledge of that element), cert. denied, 402 U.S. 945 (1971); see United States v. Hooper, 432 F.2d 604, 605 (D.C. Cir. 1970) (questioning cumulative federal-District sentences for offenses "factually the same crime, except for the addition of a federal element of which defendant had no knowledge"); see also U.S. NAT'L COMM'N ON REFORM OF FED. CRIMINAL LAWS, Final Report $\$ 103$ comment (1971) (jurisdiction not element of offense because not relevant to criminality, but only goes to power of government to prosecute); Annot., 67 A.L.R.3d 988, 1000 (1975 \& Supp. 1982) (listing cases in which jurisdictional element not required to be proved beyond reasonable doubt). But see United States v. Girst, 636 F.2d 316, 322-23 (D.C. Cir.) (separate punishments for offenses that differ only by jurisdictional element consistent with congressional intent), vacated, 645 F.2d 1014 (D.C. Cir. 1979); United States v. Butler, 462 F.2d 1195, 1198-99 (D.C. Cir. 1972) (existence of separate offenses depends on Congress', not on defendant's, intent).

At the very least, when a U.S. Code offense requires proof of only one fact in addition to those required for the D.C. Code offense to which it is joined, the D.C. Code offense should be considered a lesser included offense, and for double jeopardy purposes, greater and lesser included offenses define the "same offense." Brown v. Ohio, 432 U.S. 161, 168 (1977). The U.S. Attorney, however, does not charge D.C. Code offenses as lesser included offenses. United States v. Jones, 527 F.2d 817, 829 nn.14-15 (D.C. Cir. 1975); United States v. Hill, 470 F.2d 361, 368 (D.C. Cir. 1972).

119. United States v. Leek, 665 F.2d 383, 387 (D.C. Cir. 1981); United States v. Dorsey, 591 F.2d 922, 938-39 (D.C. Cir. 1978); United States v. Jones, 527 F.2d 817, 821 (D.C. Cir. 1975); United States v. Diggs, 522 F.2d 1310, 1323-24 (D.C. Cir. 1975), cert. denied, 429 U.S. 852 (1976); United Statcs v. Shepard, 515 F.2d 1324, 1335 n.25, 1336 (D.C. Cir. 1975); United States v. Knight, 509 F.2d 354, 361, 363 (D.C. Cir. 1974); United States v. Canty, 469 F.2d 114, 128-29 (D.C. Cir. 1972); United States v. Spears, 449 F.2d 946, 949, 954 (D.C. Gir. 1971); United States v. Hooper, 432 F.2d 604, 606 (D.C. Cir. 1970). But see United States v. Girst, 636 F.2d 316, 322-23 (D.C. Cir.) (U.S. Code weapons offense designed to augment similar D.C. Code offense, and therefore separate punishments are consistent with congressional intent), vacated, 645 F.2d 1014 (D.C. Cir. 1979).

120. The Supreme Court has held that the federal prosecutor's charging discretion is broad, and that "when an act violates more than one [U.S. Code] criminal statute, the Government may prosecute under either so long as it does not discriminate against any class of defendants." United States v. Batchelder, 442 U.S. 114, 123-24 (1979); see Bordenkircher v. Hayes, 434 U.S. 357, 364 (1978); Oyler v. Boles, 368 U.S. 448, 456 (1962); United States v. Jones, 527 F.2d 817, 820 (D.C. Cir. 
502(3) charging power may well result in harsher treatment for District defendants charged under both federal and local Codes than for defendants charged under only one Code. ${ }^{121}$

\section{Disparity of Outcome Among D.C. Code Violators}

Many defendants charged under both the U.S. and D.C. Codes and tried in federal court ultimately are sentenced only for D.C. Code offenses. ${ }^{122}$ The D.C. Circuit has ruled that this fact notwithstanding, it is "patently not feasible for the District Court to try a defendant, charged with both local and federal offenses, under differing evidentiary rules" and that therefore federal rules must apply. ${ }^{123}$ At the same time, the D.C. Circuit has permitted the use of D.C. Code evidentiary standards if all federal charges are disposed of prior to the start of evidence. ${ }^{124}$ Thus, the district court may determine which standards to apply by reference to a purely arbitrary factor: the stage of the proceeding at which all federal charges have been dismissed. Based solely on this factor, trial outcomes of federal court defendants ultimately sentenced for identical D.C. Code of-

1975); United States v. Greene, 489 F.2d 1145, 1151 (D.C. Cir. 1973), cert. denied, 419 U.S. 977 (1974).

121. In requiring the District's federal courts to read the D.C. and U.S. Codes together to determine if they define the "same offense," $\$ 11-502(3)$ creates additional confusion. To read the codes together, the D.C. Circuit must infer that Congress enacted them with the intent that they "mesh," although the Supreme Court has held that the two codes are completely separate, with different purposes and different spheres of operation. Johnson v. United States, 225 U.S. 405, 417-19 (1912). The idea that the codes "mesh," applied outside of the context of the "same offense" determination, leads to strange results. See United States v. Greene, 489 F.2d 1145, 1150-51 (D.C. Cir. 1973) (because codes mesh, U.S. Attorney may use D.C. Code felony murder statute to prosecute U.S. Code defendant in federal court, and statute encompasses U.S. Code offenses), cert. denied, 419 U.S. 977 (1974); see also Bland v. Rodgers, 332 F. Supp. 989, 990 (D.D.C. 1971) (D.C. Code charging provision applied to defendant charged with federal offense), rev'd on other grounds sub nom. United States v. Bland, 472 F.2d 1329 (D.C. Cir. 1972), cert. denied, 412 U.S. 909 (1973). But see United States v. Greene, 489 F.2d 1145, 1162 (D.C. Cir. 1973) (statement by Bazelon, J., as to why he would grant rehearing en banc) (codes not intended to mesh), cert. denied, 419 U.S. 977 (1974).

122. U.S. Code charges may be dismissed before or during trial. In addition, if a defendant is convicted of both U.S. and D.C. Code offenses that are the "same offense" for double jeopardy purposes under the rule of Blockburger, see supra note 118, the court must vacate one of the sentences. The defendant in this way may be left with only a D.C. Code conviction, see supra note 119 (cases vacating one conviction, D.C. or U.S., or remanding to the trial court with instructions to do so).

123. United States v. Belt, 514 F.2d 837, 844, 850 (D.C. Cir. 1975) (federal evidentiary standard for impeachment by prior conviction should apply to local offenders in federal court); United States v. Hairston, 495 F.2d 1046, 1054 n.13 (D.C. Cir. 1974) (same); see United States v. Brown, 483 F.2d 1314, 1318 (D.C. Cir, 1973) (federal bail rules applicable to defendant charged with D.C. Code offenses in federal court). But see United States v. Garnett, 653 F.2d 558, 561 (D.C. Cir. 1981) (unclear whether federal or District probation provision applies to D.C. Code violator in federal court).

124. United States v. Greene, 489 F.2d 1145, 1152-56 (D.C. Cir. 1973) (D.C. Code insanity standard applicable to D.C. Code violator in federal court), cert. denied, 419 U.S. 977 (1974); United States v. Brown, 483 F.2d 1314, 1320-23 (D.C. Cir. 1973) (MacKinnon, J., dissenting) (D.C. Code provisions should apply in federal court to D.C. Code defendants). But see United States v. Brown, 483 F.2d 1314, 1318 (D.C. Cir. 1973) (federal bail rules applicable to federal court defendant charged with D.C. Code offenses). 
fenses may differ materially.

The practice of using federal evidentiary standards in the federal court trial of D.C. Code offenses results in an additional disparity between federal and local court treatment of D.C. Code offenders. The different evidentiary standards applied by the two court systems-local or federal ${ }^{125}$ burdens of proof, presumptions, and tests for witness competency, for example-are substantive, and may have substantial effects upon trial outcomes. ${ }^{128}$ The difference in outcomes that may result between offenders tried for identical D.C. Code violations because of the happenstance of the court in which they are tried contradicts the fairness and uniformity principles underlying the Supreme Court's decision in Erie Railroad Co. v. Tompkins. ${ }^{127}$ Erie sacrificed uniformity among federal court decisions to achieve uniformity among federal and local courts sitting in the same jurisdiction in adjudications of local law matters. ${ }^{128}$ Erie embodies two principles equally applicable to criminal cases. The first is an equal protection principle: Litigants with similar claims should be treated similarly, regardless of the court in which those claims are adjudicated. The second is a fairness principle: Litigants with a choice between state and federal forums should not be permitted unilaterally to choose the rules and thereby affect the outcome of the litigation. ${ }^{129}$

The policies of Erie are implemented in the Federal Rules of Evidence, ${ }^{\mathbf{1 3 0}}$ which require that federal courts, when adjudicating state

125. The federal and local courts in the District use different rules of evidence. The Federal Rules of Evidence apply to federal criminal proceedings. FED. R. EvID. 1101(b). The District's local courts are not in any way bound by federal evidentiary law or the Federal Rules of Evidence, Jackson v. United States, 424 A.2d 40, 42 (D.C. 1980), cert. denied, 454 U.S. 1127 (1981), only by principles of the common law, as developed by the District's courts, D.C. R. CRIM. P. 26. Even though the D.C. Court of Appeals uses the Federal Rules of Appellate Procedure, see D.C. CODE ANN. § 11-743 (1981), and the D.C. Superior Court uses the Federal Rules of Civil and of Criminal Procedure, see D.C. CODE ANN. $\$ 11-946$ (1981), the local courts may modify even those rules to suit local needs; federal interpretations, though they may be persuasive, are not binding, Tupling v. Britton, $411 \mathrm{~A} .2 \mathrm{~d}$ 349, 351 (D.C. 1980).

126. Cities Serv. Oil Co. v. Dunlap, 308 U.S. 208, 212 (1939) (state burden of proof applied); see Ely, The Irrepressible Myth of Erie, 87 HARV. L. REV. 693, 714 (1974) (state rules concerning burden of proof, presumptions, and sufficiency of evidence must be followed where they differ from federal court practice).

127. 304 U.S. 64 (1938). It is unclear whether the Rules of Decision Act, 28 U.S.C. $\S 1652$ (1976), interpreted by the Supreme Court in Erie, encompasses District law when requiring federal courts to enforce "state law" as the Rule of Decision when determining state claims. See Ely, supra note 126, at 701-02 (rejecting "state enclave" theory as basis for Erie doctrine, opening way for Erie's application to District law as to state law); Note, supra note 62, at 980,983 (autonomy and stature of local courts require federal court use of Erie principles); see supra note 62 (discussing Erie doctrine).

128. Comment, Pendent Jurisdiction-Applicability of the Erie Doctrine, 24 U. CHI. L. REV. 543,548 (1957).

129. 304 U.S. at 75; see Hanna v. Plumer, 380 U.S. 460, 467 (1965); see also Lee v. Flintkote Co., 593 F.2d 1275, 1278 n.14 (D.C. Cir. 1979) (unfair for litigation result materially to differ because suit is brought in federal rather than local court); Comment, supra note 128, at 548; Note, supra note 62, at 983-92.

130. See C. WRIGHT, FEDERAL CoURTS $\S 93$, at 622 (4th ed. 1983) (under Federal Rules of 
claims, ${ }^{131}$ apply state substantive rules regarding presumptions as to facts that are elements of a claim or defense (including burdens of proof), ${ }^{132}$ and competency of witnesses. ${ }^{133}$ The Erie rationale also requires that federal courts trying D.C. Code offenses apply the substantive evidentiary standards found in that Code or developed by the local District courts. It is true that the Rules of Decision Act, ${ }^{134}$ interpreted by the Supreme Court in Erie, by its terms applies only to civil trials. ${ }^{135}$ Because federal courts in general may not enforce state criminal laws, ${ }^{136}$ however, there never has been a need for an Erie-type rule in criminal cases. When the Supreme Court did have the opportunity to confront a unique situation in which a federal officer, indicted by a state, removed his trial to federal court, the Court had no difficulty ruling that "the Circuit courts of the United States . . . adopt and apply the laws of the State in civil cases, and there is no more difficulty in administering the State's criminal law."137 Similarly, in the federal trial of D.C. Code charges, the federal court should "adopt and apply the laws" of the District of Columbia. ${ }^{138}$ This procedure would promote the Erie goals of treating litigants with similar claims uniformly, regardless of the court in which they find themselves situated, and of discouraging prosecutor "forum-shopping" for evidentiary rules.

Evidence, federal courts will continue to apply state-defined evidentiary "rules that in form only regulate evidence but in fact are closely associated with substantive rights").

131. Although the state claim in Erie was heard by a federal court under its diversity jurisdiction, the Erie doctrine is equally applicable to pendent state claims. Rental Car v. Westinghouse Elec. Corp., 496 F. Supp. 373, 380 (D. Mass. 1980); C. WRIGHT, supra note 130, $\S 19$, at 109.

132. FED. R. EVID. 302.

133. FED. R. EVID. 601.

134. 28 U.S.C. $\$ 1652$ (1976).

135. See United States v. Shaffer, 520 F.2d 1369, 1372 (3d Cir. 1975) (in criminal cases federal courts do not look to state law as rule of decision), cert. denied, 423 U.S. 1051 (1976); Sherman, Analysis of Federal Decisions Dealing with Evidence Published During 1967, 69 COLUM. L. REV. 377,377 (1969) (in empirical study of evidence rules applied in federal court, almost no use found of state evidentiary law in federal criminal law decisions).

136. Article III courts normally have no jurisdiction over state offenses. Wisconsin v. Pelican Ins. Co., 127 U.S. 265, 289-90 (1888).

137. Tennessee v. Davis, 100 U.S. 257, 271 (1880).

138. Even prior to the Court Reform Act, the Supreme Court refused to substitute its judgment on evidentiary matters for that of the local courts, creating, in effect, a quasi-Erie doctrine for those courts. Griffin v. United States, 336 U.S. 704, 712-18 (1949); Fisher v. United States, 328 U.S. 463, 476 (1946). The Court approached local rules in the territories with the same degree of deference. De Castro v. Board of Comm'rs, 322 U.S. 451,459 (1944) (policy reason for Erie equally applicable to territorial courts). The Supreme Court recently has departed from this long-standing policy of deferring to local court interpretation in Whalen v. United States, 445 U.S. 684, 687-88 (1980) (construing D.C. Code statute not yet considered by D.C. Court of Appeals rather than remanding, justifying action on grounds that deference to local courts is "a matter of judicial policy, not a matter of judicial power"); cf. Pernell v. Southall Realty, 416 U.S. 363, 369 (1973) (new court structure of the District "lends additional support to our longstanding practice of not overruling the courts of the District on local law matters 'save in exceptional situations where egregious error has been committed.' [citations omitted]. This principle . . . [is] now supported by the clear intent of Congress in enacting the 1970 Court Reform Act, [and] must serve as our guide in the present case."). 
While, as a matter of fairness to defendants, Erie requires the application of different substantive evidentiary standards to federal and to pendent local claims, the use of two standards may cause jury confusion. In these circumstances, the rule of United Mine Workers v. Gibbs requires the trial court to exercise its discretion to dismiss the pendent claims. ${ }^{139}$ The jeopardy element in criminal procedure, however, hampers the trial court's exercise of that discretion. ${ }^{140}$ The likelihood of jury confusion in such cases mandates not that local evidentiary standards be abandoned, but that the use of section 11-502(3) joinder be curtailed.

\section{Disparity of Outcome Among U.S. Code Violators}

Using section 11-502(3), the federal prosecutor is able to circumvent a U.S. Code hierarchy of greater and lesser-included charges and penalties. The prosecutor may charge a District defendant with a greater federal offense in one count, and with a lesser D.C. Code offense, instead of the parallel U.S. Code provision, in a second count, mindful of the fact that the local provision carries a greater maximum penalty than its federal counterpart. In this way, the prosecutor ensures that if the defendant is convicted of both charges, he may receive a total sentence longer than the maximum authorized under the federal scheme. ${ }^{141}$ Alternatively, if the greater offense cannot be proved at trial, or if the defendant pleads guilty to the lesser charge as part of a plea bargain, the defendant will receive a harsher punishment than similar defendants in other federal courts who can be charged only under the U.S. Code. The district court compounds the problem of disparate treatment for District defendants by on occasion applying D.C. Code provisions to the trial of joined D.C. and U.S. Code offenses, or even of U.S. Gode offenses alone. ${ }^{142}$ Although the D.C. Cir-

139. United Mine Workers v. Gibbs, 383 U.S. 715, 727 (1966); Houlihan v. Anderson-Stokes, Inc., 434 F. Supp. 1324, 1330 (D.D.C. 1977); see C. WRIGHT, supra note 130, § 93, at 627 ("possibility of jury confusion is a recognized reason for refusing to exercise jurisdiction over a pendent state claim, and this is the course the court should follow when contradictory rules" apply).

140. See supra p. 315.

141. Sec, c.g., United States v. Leek, 665 F.2d 383, 386 (D.C. Cir. 1981) (U.S. Attorney reached outside Federal Bank Robbery Act to "circumvent the scheme's carefully crafted hierarchy of penalties"); United States v. Canty, 469 F.2d 114, 128 (D.C. Cir. 1972) ("by reaching out to a catchall assault provision in the District of Columbia Code . . . venturing outside the federal scheme, the prosecution was able to circumvent the scheme's carefully crafted hierarchy of penalties . . . [and] to obtain a sentence longer than the maximum authorized under the highest tier of the bank robbery scheme"); see also United States v. Jones, 527 F.2d 817, 832 (D.C. Cir. 1975) (Wright, J., dissenting) ("It is obvious ... that being put at risk of receiving a prison term five times as great, and actually receiving a sentence two and a half times as great, as a defendant in any other federal District Court might receive is an 'adverse consequence." ").

142. See Bland v. Rodgers, 332 F. Supp. 989, 990 (D.D.C. 1971) (D.C. Code charging provision applied to defendant charged with both federal and local offenses), rev'd on other grounds sub nom. United States v. Bland, 472 F.2d 1329 (D.C. Cir. 1972), cert. denied, 412 U.S. 909 (1973); see also United States v. Hinckley, 672 F.2d 115, 132 n.115 (D.C. Cir. 1982) (refusing to decide whether 
cuit in most cases reverses this use of the D.C. Code, ${ }^{143}$ it has not definitely ruled that D.C. Code provisions never should be applicable to U.S. Code trials in the District.

\section{Joinder and Equal Protection}

In several cases, the D.G. Circuit has acknowledged that section 11502(3) can lead to disparities in treatment among U.S. Code offenders and among D.C. Code offenders. The court has reached conflicting conclusions, however, about the legitimacy of these results.

In United States v. Jones, ${ }^{144}$ the court held that the increase in risk exposure in federal court is a classification "based on location" that "clearly" has a "rational basis."145 In a dissent, Judge Wright objected that the use of section 11-502(3) "create[s] an invidious discrimination based solely on the fact that the trial occurred within the District of Columbia."118 Later cases seem to follow this dissenting view. In United States v. Leek, ${ }^{147}$ the court noted that the district court's dual criminal jurisdiction under section 11-502(3) engenders a "potential equal protection issue",; 1 in United States v. Garnett, ${ }^{148}$ it criticized the statute's "potential for differing treatment of similarly situated defendants solely by virtue of the forum in which they are prosecuted."150 The Garnett court described section 11-502(3) as "a troublesome anomaly among federal jurisdictional statutes," 151 disagreeing with the Supreme Court's characterization of this provision as a "minor exception" to the local court's exclusive jurisdiction over local criminal cases. ${ }^{162}$

U.S. or D.C. Code insanity standard applies to U.S. Code defendants); United States v. Caldwell, 543 F.2d 1333, 1366 (D.C. Cir. 1974) (same), cert. denied, 423 U.S. 1087 (1976); United States v. Gooding, 477 F.2d 428, 431 (D.C. Cir. 1973) (deciding that federal, rather than District, nighttime search provision applies to federal court trial of federal offenses by principle that the "more specific and more recent" statute, i.e., the federal statute, should govern), aff'd, 416 U.S. 430 (1974).

143. In United States v. Hairston, 495 F.2d 1046 (D.C. Cir. 1974) the court noted that to apply D.C. Code evidentiary provisions to U.S. Code defendants

would place criminal defendants prosecuted in the federal courts of the District of Columbia on a different footing from those tried in any other federal circuit, although both classes of defendants may be charged under the same U.S. Code provisions. This treatment of similarly situated persons in a different fashion is fraught with equal protection overtones . . . .

Id. at 1051-52 (quoting United States v. Henson, 486 F.2d 1292, 1309 n.20 (D.C. Cir. 1973)); United States v. Thompson, 452 F.2d 1333, 1341 (D.C. Cir. 1971) (D.C. Code bail provision may not be applied to U.S. Code defendant), cert. denied, 405 U.S. 998 (1972).

144. 527 F.2d 817 (D.C. Cir. 1975).

145. Id. at 821-22 \& n.6.

146. Id. at 832 (Wright, J., dissenting).

147. 665 F.2d 383 (D.C. Cir. 1981).

148. Id. at $388 \mathrm{n} .43$.

149. 653 F.2d 558 (D.C. Cir. 1981).

150. Id. at 561 .

151. Id.

152. Palmore v. United States, 411 U.S. 389, 392 n.2 (1973). 
Despite its awareness of the problems raised by section 11-502(3), the D.C. Circuit has not taken any steps to limit the use of the statute. ${ }^{163}$ The court did limit another Court Reform Act jurisdictional statute, however, reading it narrowly in light of Congress' overriding intent of separating federal and local court jurisdiction. ${ }^{154}$

\section{Congressional Intent and Efficiency Considerations}

The D.C. Circuit has also reached conflicting conclusions about Congress' purpose in enacting section 11-502(3). The only legislative history existing for the section is the following short paragraph:

Some overlapping of jurisdiction will inevitably remain, that being only a minor percentage of cases primarily arising when the same person is accused of infractions which are both Federal and purely local violations (and in those cases the United States Attorney will handle all charges with minimal procedural difficulties). ${ }^{155}$

In United States v. Jackson, ${ }^{156}$ the court pointed out that the confusion engendered by section 11-502(3) joinder "belies the optimism of the House Committee's parenthetical remark." Congress, said the Jackson court, "simply did not consciously confront the sort of problem" that the statute creates. ${ }^{157}$

The court in United States v. Shepard ${ }^{158}$ interpreted the section differently, finding that its mere existence demonstrates that Congress had determined that "the District court was to be the preferred forum whenever federal and local offenses were joinable in the same indictment and that a single trial was to be preferred over two separate trials."168 Writing in

153. The D.C. Circuit and Congress are the only authorities that may place limits on the use of $\S$ 11-502(3), since the Home Rule Act expressly forbids the District Council from regulating federal court jurisdiction. D.C. CODE ANN. § 1-233(a)(8) (1981). In United States v. Jackson, 562 F.2d 789, 793 (D.C. Cir. 1977), the court did mention that the U.S. Attorney should not be able to confer jurisdiction on the federal court by the "simple expedient of adding at least one federal count to any indictment. Plainly, this would be an unacceptable situation" in light of Congress' clear Court Reform Act intent to vest jurisdiction over local offenses in the local courts.

154. Thompson v. United States, 548 F.2d 1031, 1036-37 (D.C. Cir. 1976) (limiting reach of D.C. CODE ANN. §11-301 (1981)). The court in Thompson held that an expansive reading of the statute, which on its face seems to grant broad power to the D.C. Circuit to review local decisions, would "defy the overarching congressional intent that the courts in the District of Columbia be reconstituted into separate and independent systems." Id. at 1036. By contrast, a narrow reading, allowing review only for a limited period of time, "is at once more in accord with Congress' 'federalization' scheme [for the District] and more nearly symmetrical with others of the provisions . . . in the Court Reform Act." Id. at 1037.

155. H.R. REP. No. 907, 91st Cong., 2d Sess. 33 (1970).

156. 562 F.2d 789 (D.C. Cir. 1977).

157. Id. at 799 .

158. 515 F.2d 1324 (D.C. Cir. 1975).

159. Id. at 1330 . 
dissent in United States v. Jackson, Judge MacKinnon described section $11-502(3)$ as "serv[ing] the convenience of defendants, the Government, the witnesses, lawyers, and grand and petit juries. . . . Congress intended to insure that both types of offenses were prosecuted with the least complications possible."'160

It is a truism that in criminal cases, fairness to defendants must be accorded great weight, and that efficiency and resource conservation goals should play a more limited role than in the civil context. ${ }^{161}$ Because of the restrictions upon the trial court's supervisory power over joined local claims in criminal trials, however, the effect of section 11-502(3) joinder is to accord less fairness to criminal defendants in the District than to civil litigants.

In evaluating the joinder provision, the public interest requires a balancing of the unfairness to defendants resulting from its use against its potential for increasing efficiency or conserving judicial resources, with less weight given to efficiency than in the civil context. There are two different types of joinder that occur under section 11-502(3): joinder of charges that define the "same offense," and joinder of charges that define different offenses, but arise out of the same criminal transaction. "Same offense" joinder and "same transaction" joinder have different efficiency and fairness properties, and must be evaluated individually.

Charges that define the "same offense" cannot be separately prosecuted without violating double jeopardy. ${ }^{162}$ When these charges are prosecuted together, if convictions on both U.S. and D.C. Code "same offense" counts are returned by the jury, one conviction must be vacated. ${ }^{\mathbf{1 6 3}}$ Joinder in these circumstances does not promote efficiency; instead it may hamper it by forcing the D.C. Circuit to police trial court convictions to ensure that

160. 562 F.2d 789, 806 (D.C. Cir. 1977) (MacKinnon, J., dissenting in part).

161. The Federal Rules of Civil Procedure embody a principle of judicial economy, encouraging resolution of all aspects of a dispute in one suit; pendent jurisdiction is another tool to achieve this goal. Note, supra note 98, at 661. The principles underlying the Federal Rules of Criminal Procedure are very different. Boddie v. Connecticut, 401 U.S. 371, 390-91 (1971) (Black, J., dissenting) (contrasting constitutional "strict and rigid due process rules" that protect criminal defendants, with rules that govern civil trials. The Constitution "does not place such private disputes on the same high level as it places criminal trials and punishment."). (Justice Black's position in Boddie, that strict due process rules applicable to criminal trials normally are unnecessary in civil trials, was adopted in United States v. Kras, 409 U.S. 434, 444-46 (1973).). See Gideon v. Wainwright, 372 U.S. 335, 344 (1963) (constitutional emphasis on procedural and substantive safeguards for criminal defendants); see also United States v. Jackson, 562 F.2d 789, 799 (D.C. Cir. 1977) ("as a general matter, wholesale importation of civil law concepts into the criminal sphere is a practice fraught with danger. . . . Efficiency-'the conservation of judicial energy and the avoidance of multiplicity of litigation'-[which] may be pursued with single-minded devotion in the rules and doctrines of civil procedure," in criminal procedure "must sometimes give way to the need to protect the rights of defendants"); $8 \mathrm{~J}$. MOORE, supra note 116, I 8.02[1] ("The civil model ... is often inappropriate in criminal procedure, and no subject illustrates this fact better than joinder.").

162. See supra note 118 .

163. See supra p. 317. 
no dual jury convictions for the "same offense" are permitted to stand. ${ }^{164}$

In contrast, there undoubtedly are efficiency gains from joining charges arising from a single criminal transaction that otherwise would have to be prosecuted in separate federal and local court trials. ${ }^{165}$ "Same transaction" joinder, however, itself promotes further discrimination against District residents, by singling them out for routine dual prosecutions under both federal and local Codes. State defendants are treated differently; only in extraordinary circumstances will they be prosecuted by the United States following a state court prosecution for the same criminal act. ${ }^{\mathbf{1 8 6}}$

"Same offense" joinder should not be permitted, first, because the possibility of dual convictions is much greater when violations of two Codes have been charged than in ordinary trials, and second, because there is no efficiency justification for "same offense" joinder to balance the prejudice it creates. But it is impossible for the prosecutor to determine in advance which charges will result in convictions, and, accordingly, whether two offenses of conviction will define the same or different offenses. Thus, im-

164. See supra note 119 (D.C. Circuit may vacate either D.C. or U.S. sentence, or may remand to trial court with instructions to do so).

165. The D.C. Circuit has justified $\S 11-502(3)$ joinder of all offenses arising out of the same transaction on the grounds that joinder places District defendants and defendants in the fifty states on an equal footing: The latter may be prosecuted by both their federal and state sovereigns for a single criminal act, but District defendants may be prosecuted only by the federal sovereign. The court reasons that the double jeopardy clause requires a single proceeding for prosecution of District defendants for U.S. and D.C. Code offenses. See United States v. Alston, 609 F.2d 531, 537 (D.C. Cir. 1979), cert. denied, 445 U.S. 918 (1980); United States v. Jones, 527 F.2d 817, 821 (D.C. Cir. 1975); United States v. Shepard, 515 F.2d 1324, 1331 (D.C. Cir. 1975); United States v. Canty, 469 F.2d 114, 128-29 n.20 (D.C. Cir. 1972). The double jeopardy clause, however, does not prevent the U.S. Attorney from prosecuting a District defendant in separate proceedings for different D.C. and U.S. Code offenses arising out of the same act or transaction. The Supreme Court has not adopted the "same transaction" test, first used to define a "criminal unit" for double jeopardy purposes by Justice Brennan in a concurring opinion in Ashe v. Swenson, 397 U.S. 436, 449, 453-54 (1970). Instead, the test of Blockburger v. United States, 284 U.S. 299, 304 (1932), remains the accepted guide for determining when two separately defined crimes constitute the "same offense" for double jeopardy purposes. Simpson v. United States, 435 U.S. 6, 11 (1978).

166. The premise behind the idea that $\S 11-502(3)$ will equalize defendants, i.e., that defendants in the fifty states, unlike District defendants, may be prosecuted twice for the same act by both state and federal sovereigns, by and large is a myth. By a policy of 25-years' standing, the Justice Department will not prosecute a defendant for an act for which he already has been brought to trial in a state court, other than "in instances of peculiar enormity, or where the public safety demand[s] extraordinary rigor." Rinaldi v. United States, 434 U.S. 22, 28 (1977) (per curiam) (citing Fox v. Ohio, 46 U.S. (5 How.) 410, 435 (1847)); see Note, The Problem of Double Jeopardy in Successive Federal-State Prosecutions: A Fifth Amendment Solution, 31 STAN. L. REV. 477, 486-96 (1979). In addition, over half the states bar state proceedings following federal proceedings in certain circumstances. See Vestal \& Gilbert, Preclusion of Duplicative Prosecutions: A Developing Mosaic, 47 MO. L. REV. 1, 32-36 (1982); see also United States v. Knight, 509 F.2d 354, 361 (D.C. Cir. 1974) (per curiam) ("[T]he problem . . . is not insignificant when persons in the District of Columbia are branded for both federal and District of Columbia Code felonies for what is essentially a single transaction. The problem is accentuated, and with constitutional considerations, if persons in every state of the Union committing the same act are not put under a multiple federal-state brand-whether because of constitutional barriers or because of the realistic consideration . . . that except in unusual or emergency cases there is no sound warrant for multiple federal and state convictions even assuming constitutional authority."). 
permissible joinder cannot be separated at the outset from efficient joinder. As a consequence, both types of joinder under section 11-502(3) should be curtailed, for whatever efficiency gains are realized by the statute cannot justify its effects.

The hierarchies of D.C. Code criminal offenses and penalties are flexible, as are the U.S. Code hierarchies. In most instances the public interest and the interests of defendants are best served by a trial of D.C. Code offenses in the local court, or instead by a trial in the federal court of U.S. Code offenses only.

\section{Conclusion}

The interests of residents of the District can best be protected if their legal relationship to Congress in its dual role as the District's federal and local sovereign is both consistent and well-defined. Because of the current ambiguous status of District local law, prosecutors and judges may construe that law at whim as either federal or local. Criminal defendants in the District are particularly prejudiced by this easy definitional manipulation, since the use of either federal or local standards at any stage of the criminal justice process, from bail to parole, may easily be justified. The safest way to prevent these ill effects is to establish three presumptions. First, when Congress enacts laws of nationwide applicability, it should not be permitted to single out District residents for different treatment, using the justification that its powers over the District are "plenary" in nature. Second, when Congress exercises its authority as a state legislature for the District, it should choose to be bound by constitutional principles that define and delimit the relationship between states and their citizens. Third, the principles that govern the interactions between federal and state courts also should govern the dual court system in the District.

These presumptions would bring to light and hold up for scrutiny legislation like section 11-502(3), which is inconsistent with the presumptions of uniformity and of a federal-state court relationship, and which in addition creates classifications that discriminate against District residents. In view of the longstanding restrictions upon the exercise by District residents of political rights, as well as their inability to effect a repeal of section 11-502(3) or to prevent its use by the United States Attorney, ${ }^{167}$ these classifications must be judged with particular scrutiny. ${ }^{168}$ The D.C. Gircuit has held that "[i]t is not enough for such classifications to be

167. D.C. CODE ANN. \& 1-233(a)(8) (1981).

168. Nationally disenfranchised District residents "occupy a profoundly anomalous position in the federal system," United States v. Thompson, 452 F.2d 1333, 1340 (D.C. Cir. 1971), cert. denied, 405 U.S. 998 (1972), and may be classified as "a paradigmatically powerless class politically." See J. ELY, DEMOCRACY AND DISTRUST 83 (1980). 


\section{D.C. Jurisdiction}

merely rational or even plausible; the justification offered must actually be convincing." ${ }^{169}$ Section 11-502(3) joinder does not meet this requirement.

169. Thompson, 452 F.2d at 1341; see United States v. Brown, 483 F.2d 1314, 1317 n.14 (D.C. Cir. 1973). Thompson noted that "we normally depend upon the vote as "preservative of other basic civil and political rights," 452 F.2d at 1341 (quoting Reynolds v. Sims, 377 U.S. 533, 562 (1964)), but "it is senseless to remit District residents to the political process, since for them there is no political process." In the District "the normal arguments for judicial restraint become no more than hollow shibboleths grotesquely detached from the logic which once supported them. There is no reason to pay deference to the views of a representative body which does not in fact represent those against whom it is discriminating." Thompson, 452 F.2d at 1341. 